\title{
2 The Early Miocene "Bisciaro volcaniclastic event" (northern Apennines, Italy): a key study for the geodynamic evolution of the central-western Mediterranean
}

\author{
5 Francesco Guerrera • Manuel Martín-Martín · \\ 6 Giuliana Raffaelli $\cdot$ Mario Tramontana
}

Received: 17 April 2014 / Accepted: 12 December 2014

(C) Springer-Verlag Berlin Heidelberg 2014

\begin{abstract}
The Early Miocene Bisciaro Fm., a marly limestone succession cropping out widely in the UmbriaRomagna-Marche Apennines, is characterized by a high amount of volcaniclastic content, characterizing this unit as a peculiar event of the Adria Plate margin. Because of this volcaniclastic event, also recognizable in different sectors of the central-western Mediterranean chains, this formation is proposed as a "marker" for the geodynamic evolution of the area. In the Bisciaro Fm., the volcaniclastic supply starts with the "Raffaello" bed (Earliest Aquitanian) that marks the base of the formation and ends in the lower portion of the Schlier Fm. (Late Burdigalian-Langhian p.p.). Fortyone studied successions allowed the recognition of three main petrofacies: (1) Pyroclastic Deposits (volcanic materials more than $90 \%$ ) including the sub-petrofacies 1A, Vitroclastic/crystallo-vitroclastic tuffs; $1 \mathrm{~B}$, Bentonitic deposits; and 1C, Ocraceous and blackish layers; (2) Resedimented Syn-Eruptive Volcanogenic Deposits (volcanic material 30-90\%) including the sub-petrofacies 2A, High-density volcanogenic turbidites; $2 B$, Low-density volcanogenic turbidites; 2C, Crystal-rich volcanogenic deposits; and 2D, Glauconitic-rich volcaniclastites; (3) Mixing of Volcaniclastic Sediments with Marine Deposits (volcanic material 5-30 \%, mixed with marine sediments: marls, calcareous marls, and marly limestones). Coeval volcaniclastic deposits
\end{abstract}

\section{F. Guerrera · G. Raffaelli · M. Tramontana}

Dipartimento di Scienze della Terra, della Vita e dell'Ambiente, (DiSTeVA), Università degli Studi di Urbino "Carlo Bo", Campus Scientifico "Enrico Mattei”, 61029 Urbino, Italy

\section{Martín-Martín ( $\square)$}

Departamento de Ciencias de la Tierra y del Medio Ambiente, Universidad de Alicante, Campus San Vicente, San Vicente del Respeig, AP 99, 03080 Alicante, Spain

e-mail:manuel.martin@ua.es recognizable in different tectonic units of the Apennines, Maghrebian, and Betic Chains show petrofacies and chemical-geochemical features related to a similar calc-alkaline magmatism. The characterization of this event led to the hypothesis of a co-genetic relationship between volcanic activity centres (primary volcanic systems) and depositional basins (depositional processes) in the Early Miocene palaeogeographic and palaeotectonic evolution of the central-western Mediterranean region. The results support the proposal of a geodynamic model of this area that considers previously proposed interpretations.

Keywords Volcaniclastic event · Early Miocene · Umbria-Romagna-Marche Apennines · Stratigraphy · Petrography $\cdot$ Mediterranean-scale correlations . Geodynamic model

\section{Introduction}

Sedimentary rocks with significant volcanic clast populations are widespread in the Cenozoic central-western Mediterranean (Apennines-Maghrebian chains and Betic Cordillera). Volcaniclastic deposits are usually consistent with periods of pene-contemporaneous volcanic activity and therefore indicators of coeval magmatic geodynamic process. For this, it is useful to clarify four main aspects at least broadly treated in this paper, among others related to palaeogeographic questions: (1) lithostratigraphic characters and age relationships between successions containing volcaniclastic material (especially correlation of the ages of the sediment containers and those of the volcanic supply); (2) minero-petrographic and geochemical composition of volcaniclastites and their relationships with the original volcanism; (3) depositional process (epiclastic and/or

\begin{tabular}{|llll|}
\hline Journal : Large 531 & Dispatch : 27-12-2014 & Pages : 24 \\
Article No : $\mathbf{1 1 3 1}$ & $\square$ LE & $\square$ TYPESET \\
MS Code : IJES-D-14-00133 & $\square \quad C P$ & $\square$ DISK \\
\hline
\end{tabular}


pyroclastic) of volcanic material; and (4) bearing between sedimentary source area and volcanic supply.

A good example of these kinds of deposits is found in the Early Miocene Bisciaro Fm. (Umbria-RomagnaMarche Apennines), which can be correlated with similar coeval volcaniclastic sediments recognizable in several units of the central-western peri-Mediterranean chains.

General criteria to discriminate neo-volcaniclastic deposits, related to active pene-contemporaneous volcanism, from palaeo-volcanic detritus derived from the erosion of ancient volcanic rocks, are discussed by several authors (e.g. Pettijohn et al. 1972; Zuffa 1985, 1987; Guerrera and Veneri 1989; Critelli and Ingersoll 1995; Critelli et al. 2002; Caracciolo et al. 2011, 2012, among others). The deposits investigated here refer to the first type (i.e. volcaniclastic sediments formed during contemporaneous volcanic activity). In the present paper, the term "epiclastic" (sensu Cas and Wright 1987) is used to indicate an erosion and reworking in sub-aerial and/or submarine environments of lava flows and pyroclastites with successive re-deposition in a marine basin through mass flow processes. By contrast, "pyroclastic" indicates fallout deposition related to pyroclastic explosions or pyroclastic flows with direct sedimentation in a marine basin by decantation and characterized by different proportions of ash, crystals, and lithics. This simple basic distinction involves a different type of interpretation regarding the reconstruction of volcano position with respect to the basin areas.

Generally, in deep to shallow marine environments, the composition of volcano-derived material depends on eruption styles (effusive vs. explosive). Fragmentation of lava flows, in intra-basinal systems or on the fringes of volcanic islands, gives rise predominantly to volcano-lithic sandstones, whereas sub-aerial to shallow marine pyroclastic eruptions may result into syn-eruptive tuffaceous sandstones (ash turbidites) to vitric-crystal-rich volcanic sandstones (Cas 1979; Wright and Mutti 1981; Fisher 1984; Cas and Wright 1987; Critelli and Ingersoll 1995).

In the Late Oligocene-Early Miocene, the western Mediterranean was characterized by a calc-alkaline magmatism forming volcanic arc systems that fed the volcaniclastic sedimentation frequently interbedded in several marine formations of the Betic Cordillera, Maghrebides, and Apennines. The aim of this paper is to present an interdisciplinary study concerning the Bisciaro Fm. corresponding to a "volcaniclastic event" considered in the context of the whole depositional basin of the Umbria-Romagna-Marche Apennines. This formation has been studied regarding the stratigraphic record, the distribution of volcaniclastic materials within the succession, mineralogical and petrographic features, and depositional processes. The data compiled allow correlations with other coeval volcaniclastic sediments of some chains of the central-western Mediterranean area. The chief part of this research is to propose palaeogeographic relationships between the depositional area of the volcaniclastic sediments of the "Bisciaro event" and the location of the primary volcanoes that fed this type of sedimentation.

The results lead the "Bisciaro volcaniclastic event" to be considered a key for understanding the relationships between volcaniclastic marine sediments and volcanic source areas. At the same time, our findings help to reconstruct the geodynamic regional framework of the developing Apennine-Maghrebian Chains. Palaeogeographic and geodynamic constraints derived from the study will be discussed, and an Early Miocene evolutionary model of central-western peri-Mediterranean will be proposed.

\section{Geological framework}

The Umbria-Romagna-Marche Apennines (Fig. 1) represent a thrust-fold belt forming an arc bounded eastwards by the Sibillini thrust and its northward extension. This Apennine sector has been thrusted by the External Tuscan and External Liguride Nappes. The chain is typified by faulted E-vergent asymmetric anticlines affecting the MesozoicTertiary sedimentary succession. These anticlines are separated by narrow, often markedly asymmetric, synclines. The Umbria-Romagna-Marche Apennines have been traditionally considered to be a thin-skinned thrust-and-fold chain (Bally et al. 1988, and references therein), but more recently, a deformation involving the Hercynian basement has been pointed out (Lavecchia et al. 1994; Barchi et al. 1998; Coward et al. 1999; Mazzoli et al. 2001, 2005).

The Umbria-Romagna-Marche Apennines are characterized by a sedimentary succession deposited over a Hercynian continental crust (westward margin of the Adriatic Microplate), representing a portion of the northern margin of the African Plate. The Alpine geological history of the Umbria-Romagna-Marche Apennines started about $200 \mathrm{Ma}$ ago, when an old continent characterized by prevailing metamorphic rocks of the previous Hercynian orogenic cycle was affected by marked extensional tectonics. This deformation caused a progressive rifting, leading to the successive development of the passive margin characterizing the southern part of the Tethys (Adriatic Margin) in the Early Jurassic (e.g. Mazzoli and Helman 1994; Turco et al. 2012; and references therein). Towards the west, the oceanic Calvana-Lucania Basin (see later) was separated the Adria continental margin by a continental Microplate (Mesomediterranean Microplate; Guerrera et al. 2005; cum bibl.). According to Critelli et al. (2008) and Perri et al. (2013), the western Mediterranean palaeogeography during the MiddleLate Trias-Early Cretaceous foreshadowed the birth of this intermediate microplate (see also Doglioni 1992).

\begin{tabular}{|llll|} 
Journal : Large 531 & Dispatch : 27-12-2014 & Pages : 24 \\
Article No : 1131 & $\square \quad$ LE & $\square$ TYPESET \\
MS Code : IJES-D-14-00133 & $\square \quad C P$ & $\square$ & DISK \\
\hline
\end{tabular}




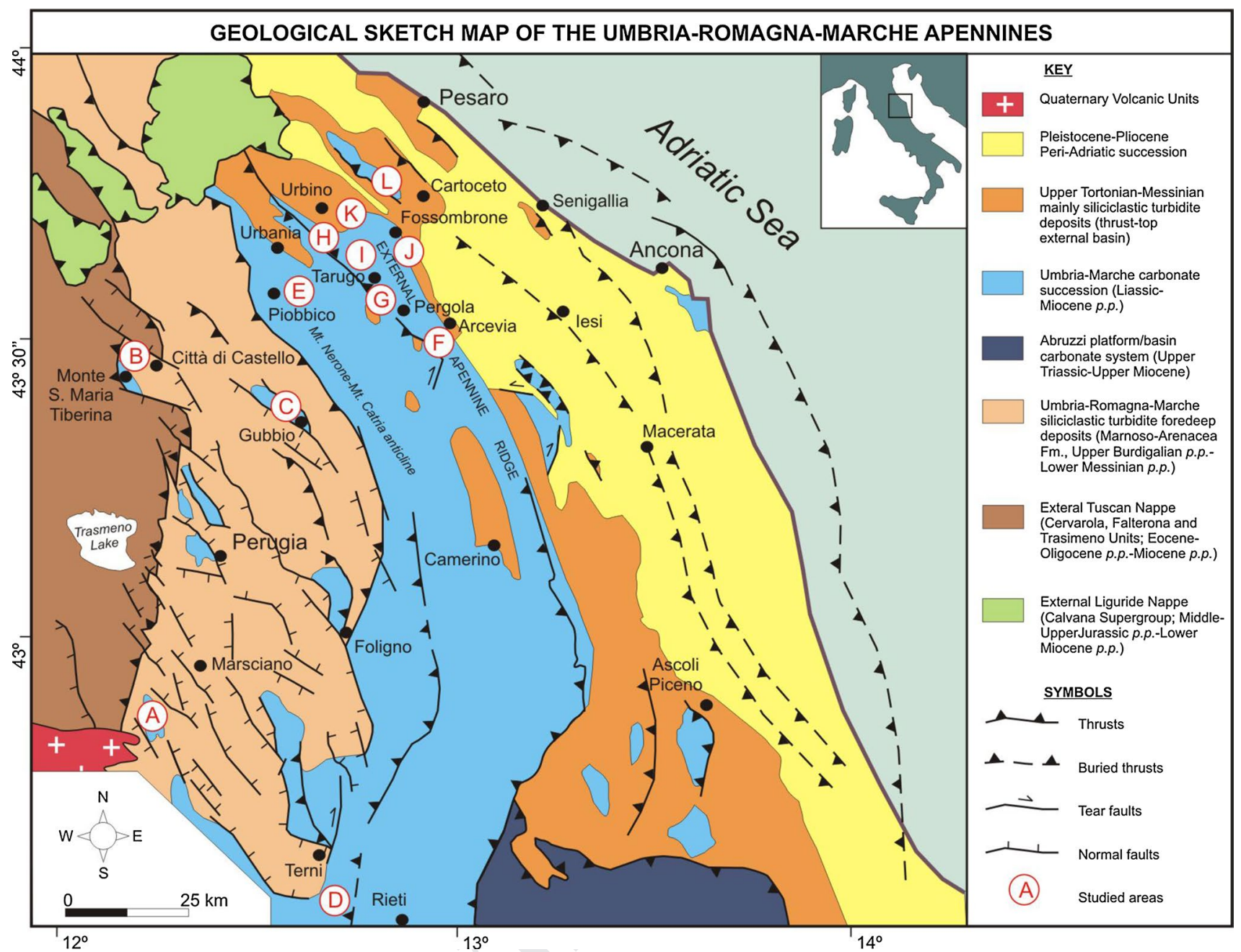

Fig. 1 Geological sketch map of the Umbria-Romagna-Marche Apennines. Location of study areas in which stratigraphic successions (logs) as shown in Fig. 2 were reconstructed, is also indicated

These passive margins developed through a progressive transition from a continental environment to a shallowwater environment (evaporitic carbonate platform) and successively to pelagic environments. Instead, in the CalvanaLucania Basin, deep marine successions developed above the Jurassic oceanic crust (Plesi et al. 2002) up to the Early Miocene (Perrone et al. 1998; de Capoa et al. 2003; Di Staso et al. 2009; and references therein).

In the Umbria-Romagna-Marche area, the succession was deposited from the Jurassic to Miocene on a Hercynian continental basement. In the lower portion of the succession, mainly carbonates were deposited during tectonic extension linked to the opening and evolution of the Tethys Ocean (Channell et al. 1979). The main Jurassic tectonic phases of the study area are related to normal faulting that controlled the development of the passive margin succession. The Jurassic sedimentation is generally continuous but shows marked lateral variations related to differences in depositional environments controlled by extensional tectonics (horst and graben system; Donatelli and Tramontana 2012, 2014; cum bibl.). During the Early Cretaceous, the depositional area reached its largest size due to drifting processes, as testified to by the maximum lateral continuity of lithofacies, due to a generalized subsidence. Cretaceous basin carbonate sedimentation has recorded the pulses of accelerated subsidence (Marchegiani et al. 1999) that could also be related to the Late Cretaceous extensional tectonics found in the carbonate platform domains (e.g. Shiner et al. 2004). Carbonate sedimentation continued up to the earliest Miocene with a progressive increase in fine clastic material, resulting in the prevalence of marly lithofacies. Early Miocene sedimentation is marked by volcaniclastic deposits representing a regional event observed in several chains of the central-western Mediterranean (e.g. Guerrera and Veneri 1989; Balogh et al. 1993; Guerrera et al. 1998; de Capoa et al. 2002; Savelli et al. 2007).

\begin{tabular}{|llll|}
\hline Journal : Large 531 & Dispatch : 27-12-2014 & Pages : 24 \\
Article No : $\mathbf{1 1 3 1}$ & $\square$ LE & $\square$ TYPESET \\
MS Code : IJES-D-14-00133 & $\square \quad C P$ & $\square$ & DISK \\
\hline
\end{tabular}


The successive Miocene sedimentation is characterized by a high amount of siliciclastic deposits showing evident diachronism proceeding towards the external Adriatic zones. The beginning of the main compressional tectonic phase is indicated by the deposition of the Marnoso-Arenacea Fm. (Miocene p.p.). Subsequently, the deformation migrated progressively towards the Adriatic Foreland to culminate in the building of the chain during MessinianPliocene times.

The sedimentation rate in the Umbria-RomagnaMarche succession is highly variable. This variability is revealed by the comparison between the Early JurassicEarly Miocene calcareous-marly group (which characterize the lower part of the succession) and the overlying Miocene siliclastic deposits. In fact, the calcareous-marly succession shows a medium thickness of about 2,5003,000 m deposited during a period of about $180 \mathrm{Ma}$ (from about. $200 \mathrm{Ma}$ to about $20 \mathrm{Ma}$ ). This indicates an average low rate of sedimentation with respect to the 3,000-m-thick siliciclastic sediments characterizing the entire diachronous clastic wedge deposited only during a period of 9-10 Ma (within the Early Miocene).

The siliciclastic deposition reflects a great palaeogeographic and geodynamic change, with the onset of sedimentary processes controlled directly by the evolution of the Apennine Chain and the migration of the related foredeep system.

\section{The "Bisciaro volcaniclastic event"}

The Bisciaro Fm. represents an Early Miocene succession in the Umbria-Romagna-Marche Apennines characterized by a high content of volcaniclastic sediments (Table 1). This volcaniclastic event represents a "marker" that can be easily recognized in other similar successions of the central-western Mediterranean area. The Bisciaro Fm. is composed of limestones, silicified limestones, and marly limestones with frequent volcaniclastic beds. The thickness ranges from $20 \mathrm{~m}$ to $100 \mathrm{~m}$ in different sectors of the Umbria-Romagna-Marche area, and the age is Aquitanian p.p.-Late Burdigalian, ranging from the upper part of the Globoquadrina dehiscens biozone to the lower part of the Globigerinoides bisphericus biozone (Guerrera et al. 2012a; and references therein) even if the upper boundary of this formation is still undefined. Several radiometric datings can be found in the literature (Balogh et al. 1993; and references therein) in good accordance with the temporal range indicated above.

This formation has previously been studied from different perspectives (Selli 1952, 1967; Mezzetti and Olivieri 1964; Mezzetti 1969; Guerrera 1977, 1979; Borsetti et al. 1984; Coccioni et al. 1988, 1989, 1994; Guerrera and
Veneri 1989; Coccioni and Montanari 1992; Mezzetti et al. 1992; Amorosi et al. 1994; Montanari et al. 1994; Guerrera et al. 1986, 1998; and references therein). The approach used in the present paper consists of a modern classification where volcaniclastic petrofacies correspond to well-identified beds outcropping in the field. Forty-one stratigraphic sections located in different sectors of the study area have been examined (Fig. 2). Sampling was conducted with particular attention to collecting the lithofacies containing volcaniclastic material.

\section{Lithostratigraphy of the Bisciaro Fm}

The stratigraphic record of the Bisciaro Fm. (Table 1; Fig. 2) shows great vertical and lateral lithofacies variability. The changes involve especially the amount and type of volcaniclastic lithofacies and the total thickness of the successions. The main feature concerns the mixing of volcanoderived products related to an intermediate to acidic volcanic composition and coeval marine sedimentation.

In the Umbria-Romagna-Marche area, the Bisciaro Fm. overlies the Scaglia Cinerea Fm. (Bartonian p.p.-Aquitanian p.p.) and underlies the Schlier Fm., ranging in age from a synchronous Late Burdigalian boundary to a markedly diachronous boundary varying in age from Early Langhian to Early Messinian (Guerrera et al. 2012a). The lower boundary is characterized by the "Raffaello" marker bed that represents the first volcaniclastic bed occurring within the Miocene succession of the Umbria-Marche Basin (Coccioni et al. 1994; Montanari et al. 1994; cum bibl.). It consists of a volcanogenic bentonitic bed (20$40 \mathrm{~cm}$ thick) well recognizable at the scale of the whole basin. The upper boundary with the overlying Schlier Fm. is not well defined because the Bisciaro/Schlier transition is very gradual without evident lithofacies changes. For some authors, this boundary corresponds to a very thin marker bed (i.e. the "Piero della Francesca" level), composed of a volcaniclastic clayey deposit attributed to the Burdigalian (about $17 \mathrm{Ma}$; Deino et al. 1997). However, the basinal extension of this marker bed has not been confirmed, and it cannot represent a lithostratigraphic boundary because: (a) it is not easily detectable; (b) it is discontinuous; (c) no real lithological changes occur below or above this level in the Bisciaro Fm.; and (d) some diluted volcaniclastic materials are also recognizable in the succession overlying this marker bed often considered as belonging to the Schlier Fm. Therefore, it is not possible to correctly define this boundary at the regional scale, and the only valid criterion to distinguish the two formations seems to be the absence of typical volcaniclastic material in the Schlier Fm. that characterize the Bisciaro one (Dubbini et al. 1992). The marly Schlier Fm. is characterized mainly by mud turbidites in the internal Umbria-Romagna zone (de Feyter 1991)

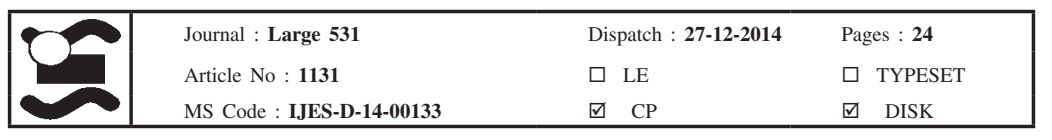




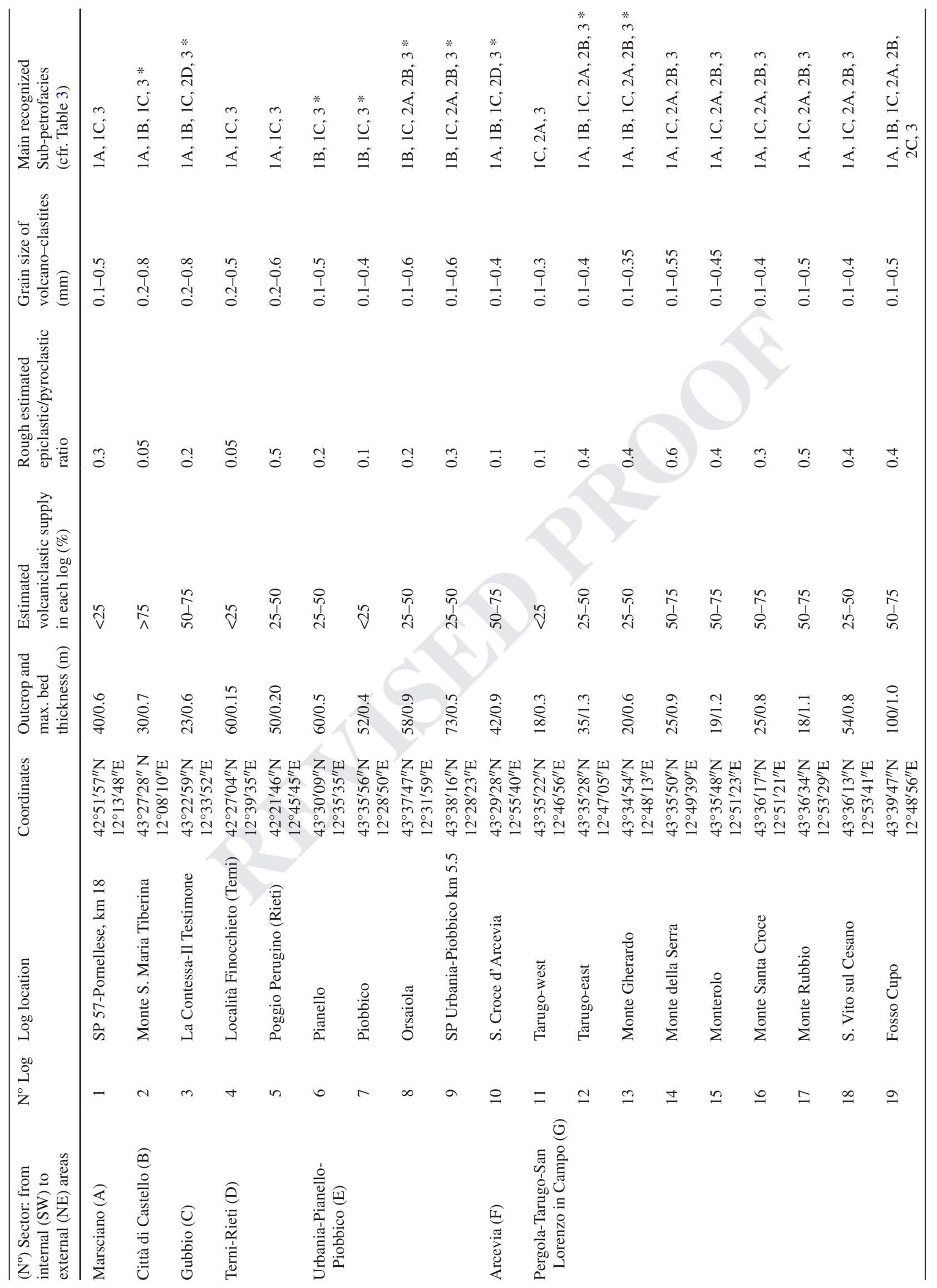

\begin{tabular}{|l|lll|}
\hline Journal : Large $\mathbf{5 3 1}$ & Dispatch : 27-12-2014 & Pages : 24 \\
Article No : $\mathbf{1 1 3 1}$ & $\square$ LE & $\square$ TYPESET \\
MS Code : IJES-D-14-00133 & $\square \quad$ CP & $\square \quad$ DISK \\
\hline
\end{tabular}




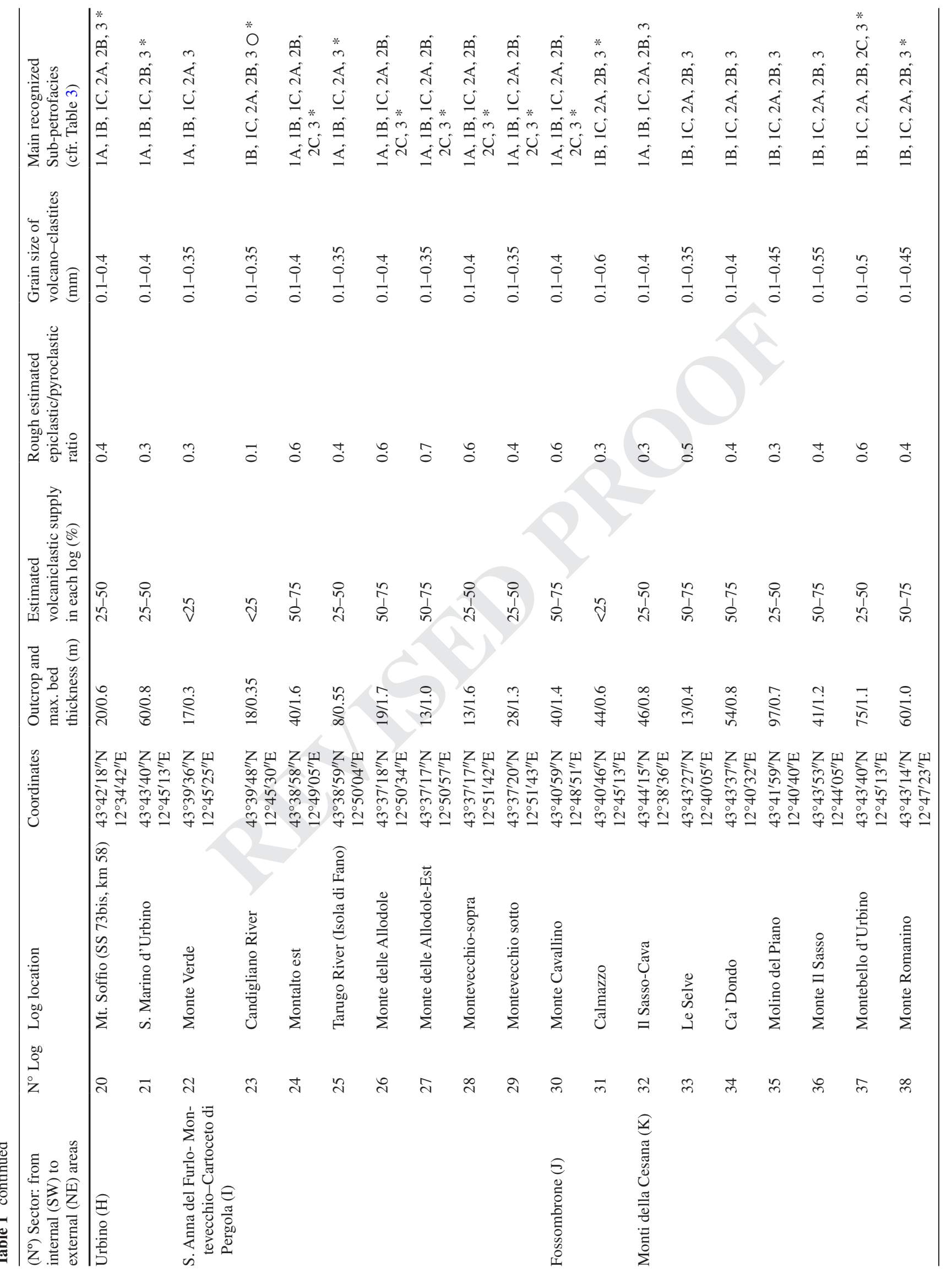

\begin{tabular}{|l|lll|}
\hline Journal : Large 531 & Dispatch : 27-12-2014 & Pages : 24 \\
Article No : 1131 & $\square \quad$ LE & $\square$ TYPESET \\
MS Code : IJES-D-14-00133 & $\square \quad C P$ & $\square \quad$ DISK \\
\hline
\end{tabular}


and by prevailing hemipelagic deposits (Dubbini et al. 1992) towards the external Adriatic domain (foreland-ramp deposition).

The Bisciaro Fm. shows an extremely varied lithostratigraphy in both thickness and lithofacies association, depending mainly on the different areal distribution of volcaniclastic materials and palaeotopography of the depositional environment. In different sectors of the northern Marche area, three members have been defined (Guerrera 1977), but these members are not recognizable in all others parts of the Umbria-Romagna-Marche Basin (cf. Geological map sheets of Umbria and Marche; CARG Project-Ispra, Roma, www.isprambiente.gov.it). As pointed out by some authors (Guerrera 1977; Guerrera et al. 1986; Balogh et al. 1993; Amorosi et al. 1994; and references therein), the volcaniclastic content can normally be found as interstratified beds or mixed with the non-volcanic marine deposits. Moreover, a significant part of the volcaniclastic material could be partially to completely altered (especially volcanic glass; Guerrera 1977), not allowing a precise or single petrographic attribution.

Petrography of volcaniclastic deposits

The volcaniclastic supply characterizing the Bisciaro Fm. originated gave rise to a large variety of products and lithofacies. The terminology used in the literature to describe the volcaniclastic products is broad and variable, and different terms are often used for the same products (e.g. field determination and/or petrographic determination).

A petrographic study in thin section (modal counting) of the study samples collected in the stratigraphic sections (Fig. 2) is reported in Table 2 and summarized in Tables 3 and 4. Microphotographs of the main petrofacies recognized in thin section and corresponding to the same petrofacies checked in the field are shown in Fig. 3. Three main types of petrofacies $(1,2$, and 3 ) resulting from eruptive mechanisms together with different depositional processes occurring in marine environment have been recognized. In types 1 and 2, eight sub-petrofacies have been distinguished.

Pyroclastic Deposits: Type 1

This type (more than 85-90\% of volcanic materials) comprises four sub-petrofacies with peculiar characters well recognizable also in the field.

Sub-petrofacies IA Vitroclastie/crystallo-vitroclastic tuffs: ash deposits (also called cinerites) that, despite the different features in the field, show homogeneous microscopic and compositional characters. In thin section (Fig. 3), tuffs are composed mainly of a skeletal fraction made up of more than $90 \%$ of volcanic materials and a

\begin{tabular}{|l|lll|}
\hline Journal : Large 531 & Dispatch : 27-12-2014 & Pages : 24 \\
Article No : 1131 & $\square$ LE & $\square$ TYPESET \\
MS Code : IJES-D-14-00133 & $\square \quad C P$ & $\square \quad$ DISK \\
\hline
\end{tabular}




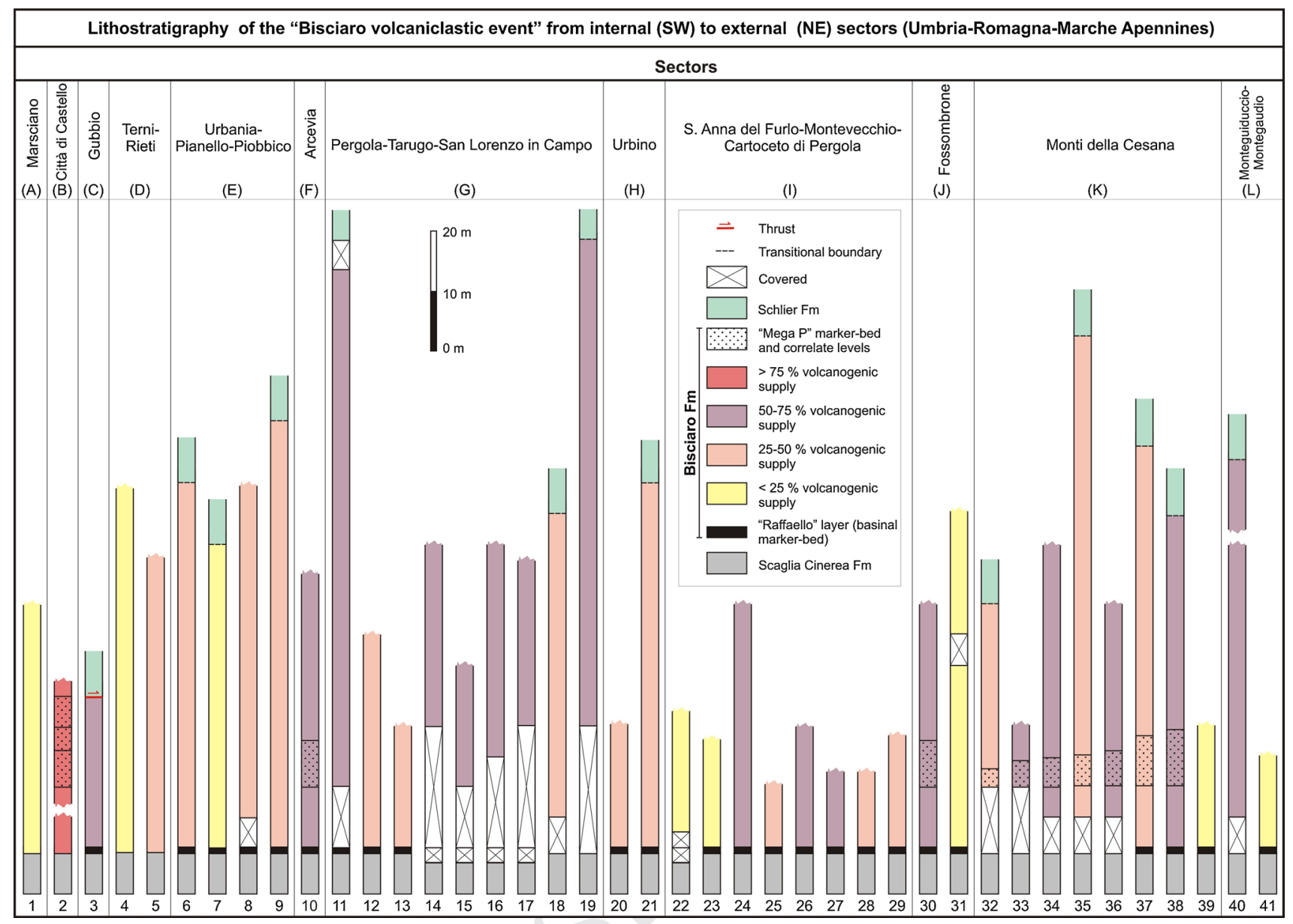

Fig. 2 Lithostratigraphy of the "Bisciaro volcaniclastic event" in the Umbria-Romagna-Marche Apennines. Numbers below columns correspond to the stratigraphic sections (logs) studied, as shown in Table 1

scarce non-volcanic fraction (Table 3). The groundmass is composed of very fine-grained components. Glass shards show cuspate, $\mathrm{X}-\mathrm{Y}$-shaped, platy shapes, bubble-wall types are almost always fresh and frequently oriented and welded in the lower part of the layers; pumice fragments are scarce. In some cases, the lower part of the cinerites show a peculiar enrichment of crystals and lithic fragments (up to $15 \%$ ) that can be fully viewed both macroscopically (showing a slight gradation) and microscopically, probably due to a gravity selection during deposition. In this case, the deposit can be better defined crystallo-vitrocastic tuff. The occurrence of smectite in the ash layers causes colour changes from grey to green, making these layers similar to the terrigenous argillaceous beds. Moreover, some finegrained deposits are interbedded with ash layers.

This sub-petrofacies may be very rich in calcite (Guerrera 1977; Guerrera et al. 1986; Balogh et al. 1993). The reference stratigraphic sections for this petrofacies are "Mt Romanino", "Montesecco", "Santa Croce di Arcevia", "Valdolmo", "Cantia", and "Marischio" (Guerrera
1977; Coccioni et al. 1988; Balogh et al. 1993; Amorosi et al. 1994). Some distinctive fine-grained ash layers have been observed in "Cantia" and "Marischio" (Amorosi et al. 1994). Chemical analyses of shards from "Santa Croce di Arcevia" and "Monte Romanino" (Tateo 1993; Morandi and Tateo 1992) indicate a dacitic to rhyolitic composition of the glass.

This sub-petrofacies also includes the so-called MegaPyroclastite ("Mega-P"; Coccioni et al. 1988) of the Bisciaro Fm., which is a made up of several overlapped cineritic beds representing an evident marker bed at the basin scale (Amorosi et al. 1994).

In the field, this sub-petrofacies is represented normally by silty and well-sorted coarse- to medium-sized sandy beds of variable thickness. About $70 \%$ of ash layers display colour changes from dark grey at the base of the beds to whitish/light grey in the upper portion. These colour variations match with the mineralogical composition of the graded beds, richer in mineral fragments at the base with respect to the top where glass shards predominate.

\begin{tabular}{|l|lll|}
\hline Journal : Large 531 & Dispatch : 27-12-2014 & Pages : 24 \\
Article No : 1131 & $\square$ LE & $\square$ TYPESET \\
MS Code : IJES-D-14-00133 & $\square \quad$ CP & $\square \quad$ DISK \\
\hline
\end{tabular}


Sub-petrofacies $1 B$ Bentitic deposites are widespread throughout the Bisciaro Fm. even if they are thicker in the lower portion of the succession. One of these thicker levels, called the "Raffaello level" (Montanari et al. 1988; Coccioni et al. 1989; Balogh et al. 1993), is well recognizable in the field, and it is normally used as a marker bed of the boundary between Scaglia Cinerea and Bisciaro Fms. Petrography of bentonitic beds (Fig. 3) shows a high content (often more than $90 \%$ ) of very fine-grained elements, together with rare crystal fragments rather fresh and secondary calcite (Table 3). This sub-petrofacies has been checked at "Gubbio-La Contessa" (Balogh et al. 1993) and other sites (Coccioni et al. 1994). The "Raffaello" marker bed can be considered the earliest explosive product of the calc-alkaline, intermediate volcanism recorded in the Umbria-Marche area (Coccioni et al. 1989). Diffraction and chemical analyses on some samples of bentonites revealed an almost monomineral composition formed by montmorillonite (often with a high crystallinity index), with a lower amount of opale-CT and clinoptilolite (Mezzetti et al. 1992; Tateo 1993).

In the field, bentonitic deposits show a colour from green to black and bright ochre/reddish-yellowish on weathered surfaces.

Sub-petrofacies tC alackish layers: this sub-petrofacies is constituted by a variable amount of very fine-grained locally oxidized minerals not being solved under the microscope with variable proportions of other components (Table 3). Very rare "exotic" minerals (e.g. muscovite, vesuvianite, and spinel) have been also detected in several stratigraphic sections (Guerrera 1977; Guerrera et al. 1986). The presence of these latter minerals may be explained, considering that the primary volcanic activity affected a crystalline basement area. This basement probably enriched the magma paragenesis. In many samples, interstitial brown glass and glass shards with the original shapes are still identifiable: this feature suggests the presence of an original vitroclastic or vitreous texture of these deposits rich in volcanic glass both as fragments and interstitial material that afterwards have been deeply altered and/or oxidized, and therefore, this deposit lacks texture. Thus, in our interpretation, these levels were originally vitroclastic and crystallo-vitroclastic tuffs now deeply altered.

This sub-petrofacies in the field appears as thin (normally a few centimetres thick, rarely decimetre) reddishocraceous, yellowish, greenish, and blackish layers with abundant iron hydroxides, probably due to the alteration of the original volcanic products. Some beds have a marked basal surface, variation in grain size (usually composed by sandy-silty grains) and highly competent without evident internal sedimentary structures (massive bedding).
Resedimented Syn-Eruptive Volcanogenic Deposits: Type 2

This type (from 30 to $90 \%$ of volcanic materials) includes four sub-petrofacies with peculiar features well recognizable also in the field.

Sub-petrofacies 21 Highensity volcanogenic turbidites: this sub-petrofacies (Fig. 3) is constituted by variable amounts of volcanic component and non-volcanic fragments (Table 3). The relative percentages of these components vary within the beds: in fact, the volcanic component decreases upwards, while the non-volcanic component increases. The related sedimentary processes are clearly sediment gravity flows (turbidity currents).

This sub-petrofacies appears in the field as dark grey volcaniclastic beds, $40-60 \mathrm{~cm}$ thick, characterized by basal erosive surfaces and graded bedding. The basal interval is characterized by medium-sized sand grains, followed by an interval with thin laminae and by an upper fine-grained massive interval. Sometimes water-escape structures are recognizable.

Sub-petrofacies $2 B$ Lensity volcanogenic turbidites: in thin sections (Fig. 3), this sub-petrofacies is characterized by predominant volcanic material with respect to the non-volcanic fraction (Table 3). This common subpetrofacies has been found in many stratigraphic sections as "Fossombrone-Monte Cavallino", "Fontecorniale-La Cava" (Guerrera et al. 1986), and in the Monti della Cesana sector. These deposits are related to sediment gravity flow processes and appear in the field as graded and laminated beds (coarse to fine sands) with a basal erosional surface, followed by an upper massive interval (fine sand to silt) often bioturbated upwards.

Sub-petrofacies $2 C$ rich volcanogenic deposits: this sub-petrofacies is constituted by crystals and fragments of crystals (up to $2 \mathrm{~mm}$ of diameter, very often oriented parallel to the stratification, both fresh or oxidized) that predominate over the other volcanic and non-volcanic fragments. This sub-petrofacies can be found as a single bed or in the lower part of the high-density volcanogenic turbidites. As these deposits are very rich in biotite crystals, they could represent almost the most abundant crystal fragments and have been indicated in the literature as "biotite inputs" (Mezzetti et al. 1992).

This sub-petrofacies is characterized in the field normally by about $40 \mathrm{~cm}$ thick clearly graded beds showing an orange yellow colour in the basal part and ocraceous grey in the upper part. These beds consist of coarse sands followed by fine sands at the base and characterized by massive deposits at the top.

Sub-petrofacies ZD ich volcaniclastites: this sub-petrofacies (Table 3) is characterized by altered vitroclastic particles, crystal fragments, and lithoclasts (prevalently found at "Contessa-Gubbio" 
Table 2 Modal point-counting analysis (in \%) of the Early Miocene "Bisciaro volcaniclastic event" studied in many successions of the UmbriaRomagna-Marche Apennines

\begin{tabular}{|c|c|c|c|c|c|c|c|c|c|c|c|c|c|c|c|c|}
\hline Sample & $\mathrm{N}^{\circ} \log$ & VI & Petrofacies & $\mathrm{VM}$ & GS & PS & Fs & FM & Qtz & VLF & NVM & NVLF & MTX & $\mathrm{Ca}$ & $\mathrm{OM}$ & Bio \\
\hline PO4 & 1 & Yellow & $1 \mathrm{~A} \mathrm{VT}$ & 95.0 & 88.0 & 6.0 & 0.5 & - & 0.5 & - & 5.0 & - & 1.0 & 3.5 & 0.5 & - \\
\hline $\mathrm{CC} 3$ & 2 & Red & $1 \mathrm{~A} \mathrm{VT}$ & 94.5 & 87.0 & 5.5 & 1.0 & - & 1.0 & - & 5.5 & - & 1.0 & 4.0 & 0.5 & - \\
\hline $\mathrm{CO} 3$ & 3 & Purple & $1 \mathrm{~A} \mathrm{VT}$ & 96.0 & 87.0 & 6.0 & 1.5 & - & 1.0 & 0.5 & 4.0 & - & 0.5 & 3.5 & - & - \\
\hline FI2 & 4 & Yellow & $1 \mathrm{~A} \mathrm{VT}$ & 85.5 & 72.5 & 10.5 & 15,0 & - & - & 0.5 & 15.0 & - & 2.5 & 12.5 & - & - \\
\hline PP6 & 5 & Pink & $1 \mathrm{~A} \mathrm{VT}$ & 95.0 & 85.0 & 6.5 & 2.0 & 0.5 & 1.0 & - & 5.0 & - & 1.5 & 2.5 & 1.0 & - \\
\hline SC7 & 10 & Purple & $1 \mathrm{~A} \mathrm{VT}$ & 95.0 & 87.0 & 4.0 & 1.5 & 1.5 & 1.0 & - & 5.0 & - & 1.0 & 3.0 & 1.0 & - \\
\hline ME7 & 24 & Purple & $1 \mathrm{~A} \mathrm{VT}$ & 97.0 & 89.0 & 4.5 & 1.5 & 0.5 & 1.5 & - & 3.0 & - & 0.5 & 2.0 & 0.5 & - \\
\hline DO6 & 34 & Purple & $1 \mathrm{~A} \mathrm{VT}$ & 87.5 & 69.0 & 10.5 & 5.5 & 2.0 & 0.5 & - & 12.5 & - & - & 5.5 & 6.5 & - \\
\hline MS1 & 36 & Purple & $1 \mathrm{~A} \mathrm{VT}$ & 95.0 & 87.0 & 5.0 & 1.5 & 0.5 & - & 1.0 & 5.0 & - & 1.0 & 2.0 & 2.0 & - \\
\hline MS2 & 36 & Purple & $1 \mathrm{~A} \mathrm{VT}$ & 97.0 & 90.0 & 4.5 & 2.5 & - & - & - & 3.0 & - & 1.5 & 1.0 & 0.5 & - \\
\hline MR4 & 38 & Purple & $1 \mathrm{~A} \mathrm{VT}$ & 93.0 & 85.5 & 3.5 & 1.0 & 1.0 & 0.5 & 1.5 & 7.0 & - & 2.5 & 3.5 & 1.0 & - \\
\hline MB2 & 37 & Pink & 1D C-VB & 85.0 & 72.5 & 10.5 & 1.5 & - & - & 0.5 & 15.0 & - & 2.5 & 12.5 & - & - \\
\hline MR1 & 38 & Purple & 1D C-VB & 85.0 & 68.0 & 9.5 & 4.5 & 1.5 & 1.5 & - & 15.0 & - & - & 6.5 & 8.5 & - \\
\hline TE33 & 12 & Pink & 2A H-DVT & 57.0 & 37.0 & 7.5 & 3.0 & 3.0 & 6.5 & - & 43.0 & 0.5 & 24.5 & 13.0 & 5.0 & - \\
\hline FC4 & 19 & Purple & 2A H-DVT & 80.0 & 70.0 & 5.5 & 3.0 & 0.5 & 1.0 & - & 20.0 & 1.5 & 4.0 & 6.0 & 2.0 & 6.5 \\
\hline FC9 & 19 & Purple & 2A H-DVT & 78.0 & 67.0 & 6.0 & 2.0 & 2.0 & 1.0 & - & 22.0 & 2.5 & 1.5 & 7.0 & 1.0 & 10.0 \\
\hline MU5 & 21 & Pink & 2A H-DVT & 53.5 & 37.5 & 6.0 & 4.5 & 2.0 & 1.0 & 2.5 & 46.5 & - & 12.5 & 12.5 & 6.0 & 15.5 \\
\hline ME4 & 24 & Purple & 2A H-DVT & 74.0 & 57.0 & 3.5 & 5.0 & 2.5 & 5.5 & 0.5 & 26.0 & 1.5 & 7.0 & 7.5 & 1.5 & 8.5 \\
\hline SS7 & 32 & Pink & 2A H-DVT & 68.5 & 52.5 & 6.5 & 4.0 & 3.5 & 2.0 & - & 31.5 & 0.5 & 12.5 & 8.5 & 2.5 & 7.5 \\
\hline DO1 & 34 & Purple & 2A H-DVT & 85.0 & 74.0 & 7.5 & 2.0 & - & - & 1.5 & 15.0 & - & 2.5 & 5.0 & 7.5 & - \\
\hline DO2 & 34 & Purple & 2A H-DVT & 70.0 & 55.0 & 3.0 & 8.5 & 2.0 & 0.5 & 1.0 & 30.0 & 5.5 & 2.5 & 5.0 & - & 17.0 \\
\hline DO3 & 34 & Purple & 2A H-DVT & 55.0 & 34.5 & 8.5 & 7.5 & 2.0 & 1.5 & 1.0 & 45.0 & 8.5 & 1.0 & 3.5 & 8.0 & 24.0 \\
\hline MS3 & 36 & Purple & 2A H-DVT & 75.0 & 57.0 & 5.5 & 10.5 & 1.5 & 0.5 & - & 25.0 & 2.5 & 3.5 & 7.5 & 1.5 & 10.0 \\
\hline MR2 & 38 & Purple & 2A H-DVT & 87.0 & 54.5 & 14.5 & 8.5 & 5.0 & 2.0 & 2.5 & 13.0 & - & - & 3.5 & 9.5 & - \\
\hline $\mathrm{CA} 2$ & 40 & Purple & 2A H-DVT & 60.5 & 56.0 & - & 4.0 & - & 0.5 & - & 39.5 & - & 38.0 & - & 1.5 & - \\
\hline $\mathrm{SC} 3$ & 10 & Purple & 2B L-DVT & 21.0 & 18.0 & - & 2.5 & - & - & 0.5 & 79.0 & - & 35.5 & 31.5 & 6.5 & 5.5 \\
\hline GH56 & 13 & Pink & 2B L-DVT & 43.0 & 25.5 & 1.7 & 7.1 & - & 8.7 & - & 57.0 & - & - & 38.0 & 9.3 & 9.7 \\
\hline CR49 & 16 & Purple & 2B L-DVT & 12.5 & 9.0 & - & 0.5 & - & 3.0 & - & 87.5 & - & - & 50.5 & 5.0 & 32.0 \\
\hline MU14 & 21 & Pink & 2B L-DVT & 47.0 & 30.5 & 7.5 & 6.0 & 1.5 & 0.5 & 1.0 & 53.0 & 5.0 & 18.5 & 14.0 & 5.5 & 10.0 \\
\hline AL5 & 26 & Purple & 2B L-DVT & 41.0 & 29.0 & 2.5 & 4.0 & - & 5.5 & - & 59.0 & 0.5 & - & 38.5 & 8.0 & 12.0 \\
\hline VS13 & 29 & Pink & 2B L-DVT & 21.5 & 14.0 & 1.5 & 3.0 & 0.5 & 2.5 & - & 78.5 & - & - & 50.0 & 2.5 & 26.0 \\
\hline MC7 & 30 & Purple & 2B L-DVT & 20.0 & 19.0 & - & 1.0 & - & - & - & 80.0 & - & - & 71.0 & 9.0 & - \\
\hline MC8 & 30 & Purple & 2B L-DVT & 20.0 & 17.5 & - & 2.5 & - & - & - & 80.0 & - & 27.0 & 18.0 & 10.5 & 24.5 \\
\hline MC9 & 30 & Purple & 2B L-DVT & 40.0 & 34.5 & - & 4.5 & - & - & 1.0 & 60.0 & - & 26.0 & 21.0 & 5.0 & 8.0 \\
\hline SS11 & 32 & Pink & 2B L-DVT & 29.5 & 24.4 & 1.5 & 2.0 & 1.0 & 0.5 & - & 70.5 & 3.5 & 1.0 & 43.0 & 4.5 & 18.5 \\
\hline MR3 & 38 & Purple & 2A L-DVT & 45.0 & 22.0 & 13.5 & 8.5 & 0.5 & 0.5 & - & 55.0 & 9.0 & 5.5 & 4.5 & 4.0 & 32.0 \\
\hline CA1 & 40 & Purple & 2B L-DVT & 42.0 & 32.0 & 0.5 & 6.5 & 0.5 & 0.5 & 2.0 & 57.0 & - & 24.0 & 32.0 & 1.0 & 1.0 \\
\hline CA3 & 40 & Purple & 2B L-DVT & 32.0 & 29.0 & - & 1.5 & 0.5 & - & 1.0 & 68.0 & 0.5 & 27.0 & 16.5 & 0.5 & 23.5 \\
\hline CA4 & 40 & Purple & 2B L-DVT & 38.5 & 35.5 & - & 2.0 & - & - & 1.0 & 61.5 & - & 25.5 & 31.0 & 0.5 & 4.5 \\
\hline CA5 & 40 & Purple & 2B L-DVT & 24.5 & 21.5 & - & 2.0 & - & - & 1.0 & 75.5 & - & 64.5 & 0.5 & 2.0 & 8.5 \\
\hline CA6 & 40 & Purple & 2B L-DVT & 28.0 & 9.0 & - & 10.0 & 4.0 & 5.0 & - & 72.0 & 4.0 & 1.0 & 62.0 & - & 5.0 \\
\hline MB1b & 37 & Pink & $2 \mathrm{C} \mathrm{CR}$ & 90.0 & 14.5 & 4.5 & 17.0 & 45.5 & 5.0 & 3.5 & 10.0 & 0.5 & 2.0 & 3.0 & 4.5 & - \\
\hline MB1t & 37 & Pink & $2 \mathrm{C} \mathrm{CR}$ & 75.0 & 12.5 & 5.0 & 12.5 & 34.5 & 4.5 & 6.0 & 25.0 & 2.0 & 4.5 & 4.0 & 3.0 & 11.5 \\
\hline DO4 & 34 & Purple & 3 & 20.0 & 8.5 & 9.0 & 1.5 & 0.5 & 0.5 & - & 80.0 & 15.5 & 5.5 & 4.5 & 9.0 & 45.5 \\
\hline
\end{tabular}

Abbreviations and symbols. $\mathrm{N}^{\circ}$ Log: Log Number (referring to Fig. 2); VI: Volcaniclastic Interval (referring to Fig. 2); VM: volcanic material; GS: glass shards; PS: pumice shards; Fs: feldspars; FM: femic minerals (pyroxene, amphibole, and biotite); Qtz: quartz; VLF: volcanic lithic fragments; NVM: non-volcanic material; NVLF: non-volcanic lithic fragments; MTX: matrix (interstitial fine-grained materials, clay minerals, glass, bioclasts); $\mathrm{Ca}$ : carbonates (carbonatic cement-like fissure filling or clast-replaced); OM: other minerals (oxides, silica minerals, and muscovite); Bio: bioclasts, values in percentages. $1 \mathrm{~A}$ VT $=$ Vitroclastic/crystallo-vitroclastic tuffs; 2A H-DVT $=$ High-density volcanogenic turbidites; $2 \mathrm{~B}$ L-DVT $=$ Low-density volcanogenic turbidites; $2 \mathrm{C} \mathrm{CR}=$ Crystal rich; 2D G-RV = Glauconitic-rich volcaniclastites; $3=$ Volcanogenic sedimentary deposits

\begin{tabular}{|llll|} 
Journal : Large $\mathbf{5 3 1}$ & Dispatch : 27-12-2014 & Pages : 24 \\
Article No : $\mathbf{1 1 3 1}$ & $\square$ LE & $\square$ TYPESET \\
MS Code : IJES-D-14-00133 & $\square \quad C P$ & $\square \quad$ DISK \\
\hline
\end{tabular}


Table 3 Detailed mineralogical composition of the recognized petrofacies

\begin{tabular}{|c|c|c|}
\hline Petrofacies & Sub-petrofacies & Mineralogical composition (in order of decreasing abundance) \\
\hline \multirow[t]{3}{*}{$\begin{array}{l}\text { Type } 1 \\
\text { (Pyroclastic Deposits) }\end{array}$} & $1 \mathrm{~A}$ & $\begin{array}{l}\text { Glassand pumice shards, plagioclase, pyroxene, amphibole, biotite, calcareous and/or } \\
\text { siliceous microfossils, rock fragments (mainly porphyric lavas), and matrix of very } \\
\text { fine-grained shards, clay minerals, rare micrite }\end{array}$ \\
\hline & $1 \mathrm{~B}$ & $\begin{array}{l}\text { Vitric particles and lithoclastic grains (altered in smectite), plagioclase, quartz, dark } \\
\text { minerals, foraminifers, secondary calcite }\end{array}$ \\
\hline & $1 \mathrm{C}$ & $\begin{array}{l}\text { Glass and pumice shards, plagioclase, quartz, clinopyroxene, lithic fragments (aphyric } \\
\text { lavas, siltstones, chert), bioclasts, secondary calcite }\end{array}$ \\
\hline \multirow{4}{*}{$\begin{array}{l}\text { Type } 2 \\
\text { (Resedimented Syn-Erupive } \\
\text { Volcanogenic Deposits) }\end{array}$} & $2 \mathrm{~A}$ & $\begin{array}{l}\text { Glass and pumices shards, plagioclase, clinopyroxene, biotite, lithic (lavas, chert, sedi- } \\
\text { mentary rocks) and bioclastic fragments, secondary calcite }\end{array}$ \\
\hline & 2B & $\begin{array}{l}\text { Glass (unaltered and mainly colourless) and pumice shards, plagioclase, clinopyroxene, } \\
\text { biotite, quartz, lava and non-volcanic lithic fragments (siltites, chert, and polycrystal- } \\
\text { line quartz), bioclasts, spatitic calcite and matrix made up of glass, micrite, clay, very } \\
\text { fine-grained bioclasts with siliceous shells (mainly diatoms), clays (illite/montmoril- } \\
\text { lonite and montmorillonite) }\end{array}$ \\
\hline & $2 \mathrm{C}$ & $\begin{array}{l}\text { Crystals mainly of biotite, plagioclase, clinopyroxene, amphibole, quartz, muscovite, } \\
\text { glass and pumice shards, bioclasts (globigerina, globorotalia, sponge spicules, echino- } \\
\text { derms, bryozoa, and radiolaria), lithic fragments (siltites, lavas, and chert) }\end{array}$ \\
\hline & $2 \mathrm{D}$ & $\begin{array}{l}\text { Glass shards, plagioclase, glauconies, dark minerals (hornblende, biotite altered to chlo- } \\
\text { rite), quartz, rare opaque minerals (mainly magnetite), volcanic lithoclasts (hyalo- } \\
\text { pilitic-pilotaxitic texture and often partly replaced by iron hydroxide), phosphates, } \\
\text { fragments of sedimentary rocks and bioclasts }\end{array}$ \\
\hline $\begin{array}{l}\text { Type } 3 \\
\text { (Mixing of Volcaniclastic } \\
\text { Sediments with Marine Deposits) }\end{array}$ & 3 & $\begin{array}{l}\text { Glass and pumice shards (altered in smectite), crystals of plagioclase, quartz, clino- } \\
\text { pyroxene, dark minerals (hornblende, often replaced by iron hydroxide, and augite), } \\
\text { lithic fragments (effusive rocks), brown/blackish rich in foraminifers matrix }\end{array}$ \\
\hline
\end{tabular}

The $\%$ of different components are shown in Table 2

and "Santa Croce d'Arcevia"; see also Balogh et al. 1993). Glauconies are represented by a transition variety between glauconite and celadonite minerals, forming mixed layers with montmorillonite (20-40 \% of montmorillonite). Glauconies also replace foraminifera shells. The volcaniclastic component of these beds is the same as that of the "Raffaello marker bed" (closer to a dacitic composition, based on the greater occurrence of biotite, hornblende).

This sub-petrofacies is recognizable mainly in the field for the high diffusion of greenish colours related to glauconies.

Mixing of Volcaniclastic Sediments with Marine Deposits: Type 3

This type includes some lithotypes characterized by a mixing with a varying content of volcaniclastic supply (from 5 to $30 \%$ of volcanic materials), which is not easily quantifiable macroscopically in the field.

Petrofacies 3 marls, calcareous marls, and marly limestones with volcaniclastic material: this petrofacies includes all the sedimentary deposits related to the marine deposition, which contain a variable amount of volcanic supply (Table 3), generally between 5 and $30 \%$. Under the value of $5 \%$, this volcaniclastic content was not considered. This petrofacies is recognizable in all stratigraphic sections. The volcanic material is similar to that of the previously described petrofacies (Table 3). Associated with the calcareous-marly lithofacies, especially in the lower part of the Bisciaro Fm., blackish silicifications (often in lens) are widespread and constituted by different phases of silica (cristobalite, opalCT, and opal-A), calcite (30-75\%), and small amounts of minerals (quartz, smectite, feldspars, and very finegrained mafics).

In the field, this petrofacies normally characterizes the Bisciaro succession and is well distinguished by typical volcaniclastic sediments. This petrofacies represents the result of the dilution of the volcaniclastic supply within the marine sedimentation that must be considered as regards the quantitative evaluation of the total volcaniclastic supply. Deposits are normally greyish and show a thin lamination. Sometimes clayey and clayey-sandy volcaniclastic layers, typically ocraceous, brownish, greenish, and blackish and frequently rich in organic matter (bituminous thin levels), are also interbedded.

\begin{tabular}{|c|c|c|}
\hline Journal : Large 531 & Dispatch : 27-12-2014 & Pages : 24 \\
\hline Article No : 1131 & $\square$ LE & $\square$ TYPESET \\
\hline MS Code : IJES-D-14-00133 & $\square \quad \mathrm{CP}$ & च DISK \\
\hline
\end{tabular}




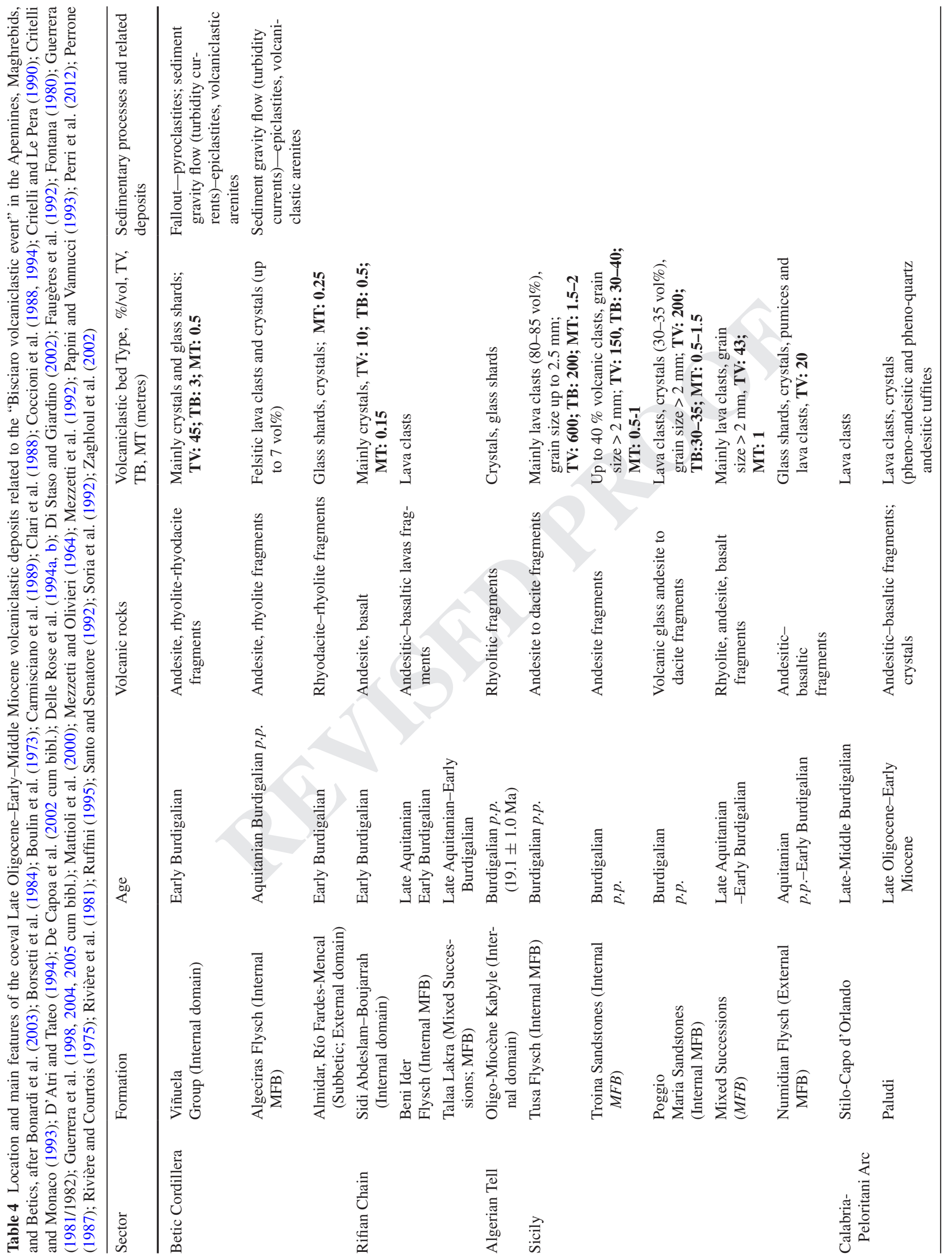

\begin{tabular}{|l|lll|}
\hline Journal : Large 531 & Dispatch : 27-12-2014 & Pages : 24 \\
Article No : 1131 & $\square$ LE & $\square$ TYPESET \\
MS Code : IJES-D-14-00133 & $\square \quad C P$ & $\square \quad$ DISK \\
\hline
\end{tabular}




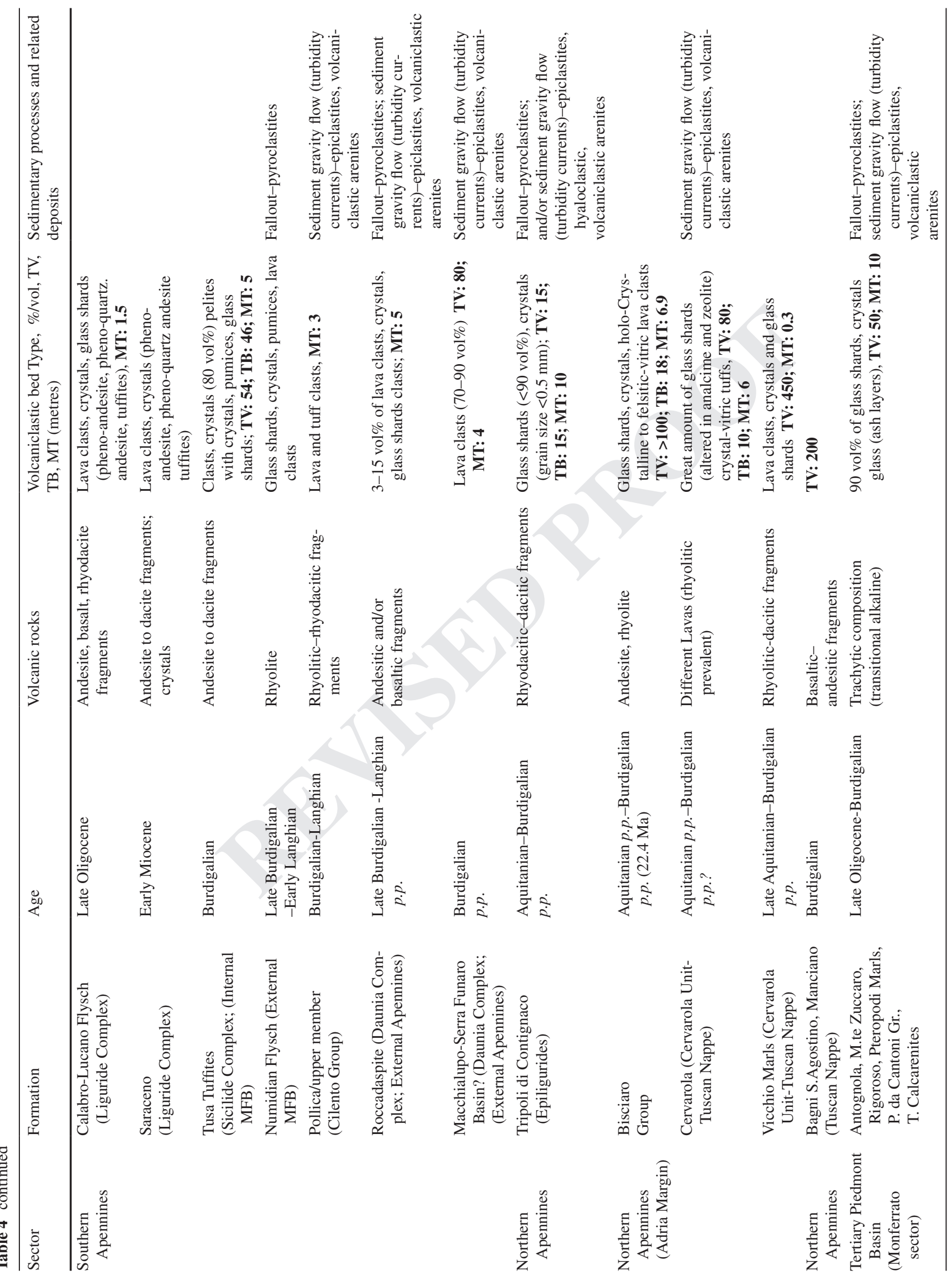


The importance of the "Bisciaro volcaniclastic event" of the Umbria-Romagna-Marche Apennines is demonstrated by the possibility of correlating this event among different sectors of Apennine, Maghrebian, and Betic Chains, where similar and contemporaneous volcaniclastic deposits occur. The coeval volcaniclastic deposits show similar petrofacies (Table 4) even if they can be interbedded within different lithologic successions.

With the aim of reconstructing the vertical and lateral distribution of these volcaniclastic deposits and making a correlation, different Early Miocene formations have been considered in the southern Alpine central-western periMediterranean area. Table 4 lists the main features of volcaniclastic deposits and sedimentary processes.

The extent of the recognized "volcaniclastic event" at a regional scale indicates that in the Early Miocene, major geodynamic processes affected the central-western Mediterranean area. Moreover, the abundance of volcaniclastic deposits, their features, and distribution indicates a great diffusion of active volcanic centres during this temporal range. This implies the necessity of recognizing their location to reconstruct a palaeogeographic and palaeotectonic picture of the portion of the Mediterranean region considered.

Meaning of the "Bisciaro volcaniclastic event"

On the basis of the above-reported features, some main considerations arise concerning the meaning of the "Bisciaro volcaniclastic event".

1. In contrast to previous interpretations, the Bisciaro Fm. represents the result of the deposition related mainly to volcanic activity occurring contemporaneously to the marine sedimentation during the Early Miocene. In fact, the hemipelagic marine deposits seem to be subordinated with respect to the volcaniclastic content, especially considering the widespread alteration processes (mainly calcification) subtracting high amounts of the original volcanic supply.

575

2. The "Bisciaro volcaniclastic event" constitutes a significant episode among many other ones strictly linked to the wide Early Miocene primary volcanic activity that is not easy to locate but occurred in the central-western Mediterranean region in areas involved in the orogenic chains during Miocene times.

3. The recognized depositional processes controlling the volcaniclastic material are represented by: (a) fallout and/or pyroclastic flows originating pyroclastic depos-

\begin{tabular}{|llll|} 
Journal : Large $\mathbf{5 3 1}$ & Dispatch : 27-12-2014 & Pages : 24 \\
Article No : $\mathbf{1 1 3 1}$ & $\square$ LE & $\square$ TYPESET \\
MS Code : IJES-D-14-00133 & $\square \quad C P$ & $\square \quad$ DISK \\
\hline
\end{tabular}


its (Types 1 and 3; Table 4) and (b) sediment gravity flows (turbidity currents) generating the volcaniclastic sediments (Types 2 and 3; Table 4). In addition, the volcaniclastic sedimentation is often represented by fine-grained ash layers, generally altered to clay minerals originating from pyroclastic and/or epiclastic deposits (Type 1: 1B and 1C and Type 3; Table 3), after their primary emplacement.

4. Even if it is not easy to define the $\%$ ratio of different kinds of volcaniclastic sediments, a rough estimation has been made in each stratigraphic succession studied (Table 1). On the basis of this evaluation, a moderate prevalence of pyroclastites with respect to epiclastites is recognizable. These results do not confirm what was assumed by Amorosi et al. (1994), who considered the volcaniclastic deposition to be exclusively the result of re-sedimentation processes. Meanwhile, other authors (Selli 1952; Borsetti et al. 1984; Mezzetti and Olivieri 1964; Mezzetti 1969; Mezzetti et al. 1992; among others) considered the pyroclastic supply to be the only type of sedimentary contribution.

5. Normally, the grain size of volcaniclastic products ranges between silt and medium- to coarse-sized sands (Table 1), implying some constraints in the reconstruction of the distance between volcanoes and sedimentary basins. Unfortunately, on the basis of our data, it is not possible to recognize the eruption styles, volcanic forms, or environment. However, the maximum grain size of the pyroclastic sediments indicates depositional areas located near the volcanic centres. By contrast, the grain size is not significant for the volcanogenic turbidites deposits because these are controlled by specific characters of related depositional processes.

6. Considering the correlations of the "Bisciaro volcaniclastic event" across the Apennines, Maghrebids, and Betics, it is necessary to identify the remnants of coeval volcanoes along these chains that are characterized by chemical affinity and located in a compatible palaeogeographic framework with respect to the distance from the depositional areas.

\section{Volcaniclastic supply and depositional processes}

Field data, stratigraphy, and petrofacies features indicate that the main processes of emplacement of volcaniclastic materials in the Bisciaro depositional area (Table 5) are represented by: (a) fallout (pyroclastic processes) and (b) sediment gravity flows (turbidity currents and epiclastic processes). The pyroclastic processes are controlled mainly by two main factors: (1) the amount of pyroclastic products during volcanic eruptions and (2) the distance of volcanic centres with respect to the sedimentary basin. The epiclastic processes imply the remobilization of volcanic material due to more or less diluted turbidity currents probably controlled by syn-sedimentary tectonics and topographic features. The palaeotopography of the depositional area was probably irregular with the presence of deep and shallow zones as pointed out by Guerrera (1977). These irregularities together with the variability of sedimentary processes normally cause a short lateral continuity of the volcaniclastic beds even if some pyroclastic deposits show a basinal correlation of up to $5 \mathrm{~km}$ (e.g. Fossombrone sector) and much more for the "Raffaello" and the "Mega-P" marker beds (Table 1; Fig. 2). The volcaniclastic supply is laterally highly variable, and a rough evaluation has been made in all the stratigraphic sections (Fig. 2).

Furthermore, the frequency of pyroclastites, the substantial correspondence between radiometric and biostratigraphic ages, the similar chemistry between pyroclastic and epiclastic products, and the freshness of volcanic glass and various other crystals and minerals demonstrate that volcanic activity and marine sedimentation were contemporaneous.

All mineralogical-petrographic and geochemical data of volcaniclastic deposits, when the literature is taken into account, imply an intermediate to acid volcanism for the source areas. This type of volcanism prompts considerations on the palaeogeographic location and distribution of volcanic systems. Generally, pyroclastic deposits provide little information on the distance between volcanoes and basins because the volcanic particles are transported by wind for long distances, and only the thickness and grain size of beds can provide more useful indications. Moreover, epiclastic deposits (turbidites) imply more palaeogeographic constraints because the expansion of mass flow processes along great distances needs a suitable palaeotopography characterized by a depositional environment without intra-basinal barriers (e.g. a building chain).

Geodynamic context

The abundance and the broad distribution of the volcaniclastic material resulting from this event imply a contemporaneous development of calc-alkaline magmatism from volcanic arc systems in different Mediterranean sectors. This primary volcanic activity occurred between 24 and $17 \mathrm{Ma}$ (Late Oligocene-Early Miocene, Table 5). It is difficult to have more information about the type of volcanoes and eruptive style because volcanoes rarely crop out and at present the related products form part of orogens. Nevertheless, petrographic data from the Bisciaro volcaniclastic deposits indicate a calc-alkaline volcanism characteristic of continental subduction zones (Andean-like). This kind of volcanism is usually related to Plinian-like eruptions and stratovolcano forms (Mahlburg-Kay and Ramos 2006). Each depositional area, of those at present in different

\begin{tabular}{llll|} 
Journal : Large 531 & Dispatch : 27-12-2014 & Pages : 24 \\
Article No : $\mathbf{1 1 3 1}$ & $\square$ LE & $\square$ TYPESET \\
MS Code : IJES-D-14-00133 & $\square \quad C P$ & $\square$ DISK \\
\hline
\end{tabular}



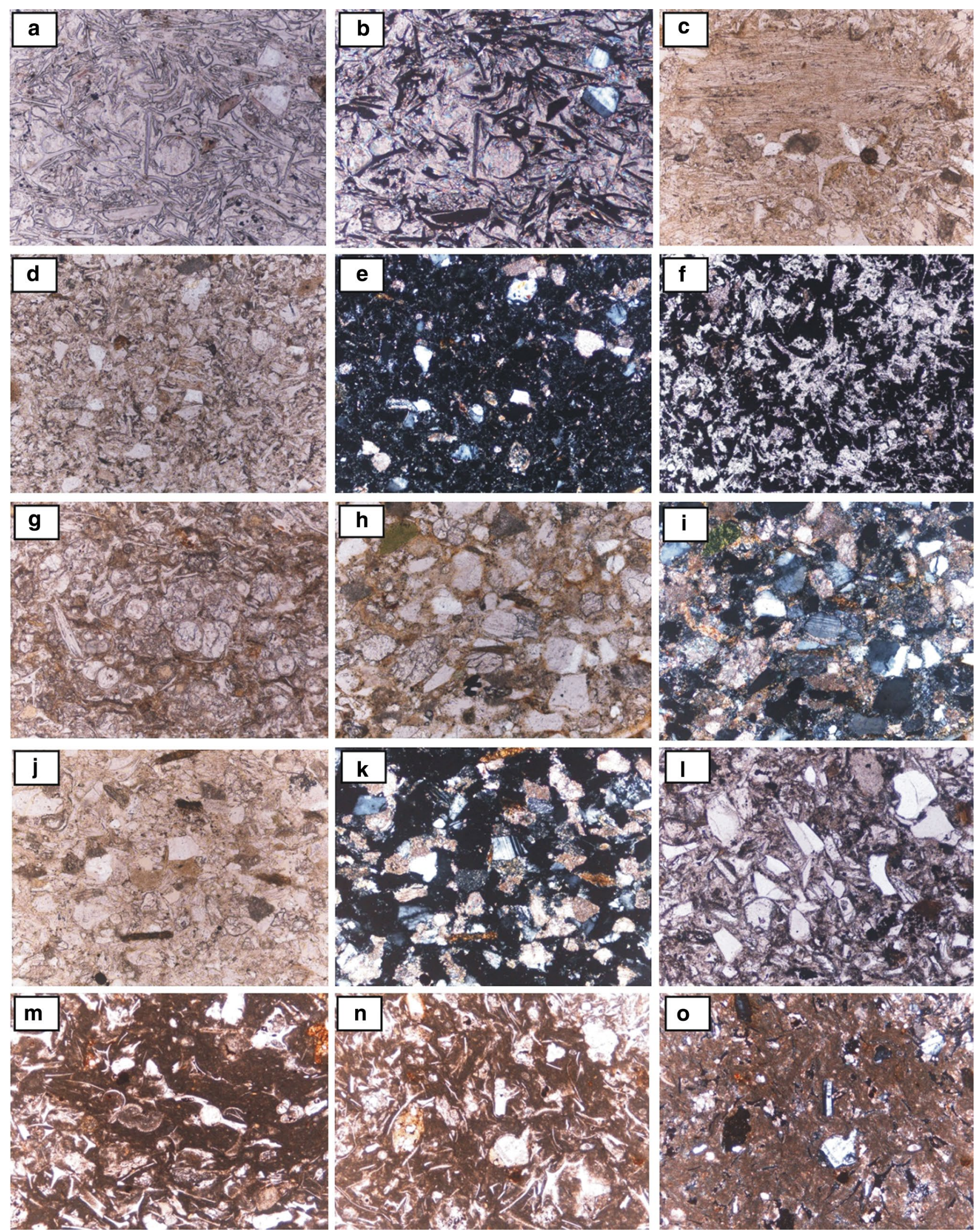

\begin{tabular}{|l|ll|} 
Journal : Large 531 & Dispatch : 27-12-2014 & Pages : 24 \\
Article No : $\mathbf{1 1 3 1}$ & $\square$ LE & $\square$ TYPESET \\
MS Code : IJES-D-14-00133 & $\square \quad C P$ & $\square \quad$ DISK \\
\hline
\end{tabular}


4Fig. 3 Optical microphotographs of some representative samples from volcaniclastic deposits of Bisciaro Fm. a, b Vitroclastic Tuff (Petrofacies 1A) from SP 57-Pornellese section: prevalent colourless glass shards with variable morphologies (platy, cuspate, and bubble) and subordinate crystal fragments (plagioclase). This sample displays a high calcite content. a Plane-polarized light, b cross-polarized light, base of the photographs $1.25 \mathrm{~mm}$. c Vitroclastic Tuff (Petrofacies 1A) from Montalto Est section: longitudinal section of a pumice shard that displays elongated parallel vescicles characteristic of vesciculation during magmatic eruptions. Plane-polarized light, base of the photograph $1.25 \mathrm{~mm}$. d, e Crystallo-Vitroclastic Tuff (Petrofacies 1A) from Poggio Perugino section: abundant glass shards with crystal fragments and lithoclasts. d Plane-polarized light, b crosspolarized light, base of the photographs $1.25 \mathrm{~mm}$. f Blackish layer (Petrofacies 1C) from Monte Cavallino section: glass shards are still well recognizable in the fine-grained oxidized matrix. Plane-polarized light, base of the photographs $2.5 \mathrm{~mm}$. g-i High-density volcanogenic turbidite (Petrofacies 2A) from Ca' Dondo (g) and Tarugo Est (h, i) sections: abundant glass shards and bioclasts and minor amounts of lithic and crystal fragments (g) and prevalence of crystals and lithic fragments (h, i). g, h Plane-polarized light, i Cross-polarized light, base of the photographs $1.25 \mathrm{~mm}$. j, k Low-density volcanogenic turbidite (Petrofacies 2B) from Fonte Corniale-La Cava section: abundant fine-grained matrix rich in glass shards, crystals, and lithic fragments. j Plane-polarized light, $\mathbf{k}$ cross-polarized light, base of the photographs $1.25 \mathrm{~mm}$. I Crystal-rich volcanogenic deposit (Petrofacies 2C) from Montebello d'Urbino section: abundant crystals and crystal fragments, glass shards, and lithic fragments. Plane-polarized light, base of the photographs $1.25 \mathrm{~mm}$. m Marl with volcaniclastic material (Petrofacies 3) from Orsaiola section: abundant glass shards and scarce crystals (plagioclase, quartz, and dark minerals), lithic fragments, and bioclasts in a very fine matrix. Plane-polarized light, base of the photograph $2.5 \mathrm{~mm}$. n, o Marl with volcaniclastic material (Petrofacies 3) from Finocchietto locality (Terni) section: very abundant glass shards and scarce crystals of fresh plagioclase and quartz. n Plane-polarized light, o crossed-polarized light, base of the photographs $2.5 \mathrm{~mm}$ chains, was linked to a related volcanic system. In fact, it would hardly be possible for only one volcanic arc to feed all Early Miocene peri-Mediterranean basins. Moreover, it is necessary to consider the different palaeogeographic and geodynamic contexts in which volcanic systems arise.

1. Iberian margin. The andesite, rhyolite-rhyodacite volcanism of the Internal Betic Zone could be related to internal subduction and thrusts in the Mesomediterranean Microplate but also to the opening of back-arc basins (Martín-Algarra 1987). The Valencia Trough is related to an "aborted rift" formed before the Early Miocene opening of the western Mediterranean Sea, leading to the Iberian Range (Maillard and Mauffret 1993) and to the present location of the Balearic Islands, which began to separate from the Iberian Peninsula in the Early Miocene (Arias et al. 2004) giving rise to a related volcanism. On the other hand, the External Betic Zone rhyodacite-rhyolite volcanism is related to the development of a main transform fault (Intra-Subbetic fault; Soria et al. 1992). Late volcanism (Middle Miocene) related to the Mediterranean
Sea opening is recognizable in the "Cabo de Gata" area (Zeck et al. 2000).

2. African margin (Rifian Chain). The andesitic and basaltic volcanism (Guerrera 1981/82; Zaghloul et al. 2002) appears to be related to the northward subduction of the African Plate beneath the southern margin of the Mesomediterranean Microplate.

3. African margin (Algerian Tell). The rhyolitic explosive phase (Monié et al. 1992) is probably connected to a northward subduction of the African Plate (Rehault 1981) beneath the southern margin of the Mesomediterranean Microplate.

4. Maghrebian Flysch Basin. In Sicily and CalabriaPeloritani Arc, mainly andesitic to dacitic and also rhyolitic volcanism has been detected (Balogh et al. 1993; de Capoa et al. 2002; Bonardi et al. 2003; Guerrera et al. 2005; Perri et al. 2012). This volcanism is probably connected with the northward subduction of the African Plate beneath the southern margin of the Mesomediterranean Microplate but also to the opening of back-arc basins.

5. Adria margin (Apennines). The volcanism recognized could be related to the westward subduction of Adria Plate even if this volcanism is considered to have high diffusion, since at present it has been found only in a few places. Two deep wells, called Mortara 1 on the Po Plain (Cassano et al. 1986) and Pieve S. Stefano 1 in the Central Apennines (Anelli et al. 1992), were drilled into Oligocene-Miocene volcanites. In Mortara 1, the available data show the presence of Early-Middle Miocene andesitic lavas of 16.1-20.9 Ma (Bonci et al. 1994) and Oligocene-Miocene andesitic to dacitic lavas (Ruffini 1995; Mattioli et al. 2002). The volcanic effusive rocks drilled at Pieve S. Stefano 1 consist of andesitic lavas of uncertain age (Oligocene-Miocene; Anelli et al. 1992). The easternmost volcanoes that have been hypothetically located above the Adria continental margin (Fig. 4) are related to the continental collision between Adria and the Mesomediterranean Microplate after the consumption of the oceanic crust of the Calvana-Lucania Basin. This collision involves the inversion of the subduction from west to east dipping direction with the continental crust of the Mesomediterranean Microplate subducting below the Adria Microplate in the last stage of subduction zone transference during the accretion of the Apennine Chain. A modelling of this type of deformation has been recently presented by Simakin (2014).

6. European margin (Sardinia Trough). The high-Mg basalt (transitional tholeiitic) volcanism (Mattioli et al. 2000) and the volcano-sedimentary successions (Assorgia et al. 1997; Guerrera et al. 2004) are presumably connected with the volcanic activity from the 
Table 5 Volcaniclastic petrofacies and recognized depositional processes of the "Bisciaro volcaniclastic event"

\begin{tabular}{|c|c|c|}
\hline Petrofacies & Sub-petrofacies & $\begin{array}{l}\text { Depositional processes of volcaniclastic } \\
\text { material }\end{array}$ \\
\hline \multirow[t]{3}{*}{$\begin{array}{l}\text { Type } 1 \\
\text { Pyroclastic Deposits }\end{array}$} & $\begin{array}{l}\text { 1A: Vitroclastic/crystallo-vitroclastic tuffs } \\
\text { (Ash layers, Cinerites) }\end{array}$ & Fallout and/or pyroclastic flows \\
\hline & 1B: Bentonitic deposits & Weathering of fallout volcanic ash \\
\hline & 1C: Ocraceous and blackish layers & Alteration of volcanic products \\
\hline \multirow{4}{*}{$\begin{array}{l}\text { Type } 2 \\
\text { Resedimented Syn-Eruptive } \\
\text { Volcanogenic Deposits }\end{array}$} & 2A: High-density volcanogenic turbidites & $\begin{array}{l}\text { Sediment gravity flow processes (turbidity } \\
\text { currents) }\end{array}$ \\
\hline & 2B: Low-density volcanogenic turbidites & $\begin{array}{l}\text { Sediment gravity flow processes (turbidity } \\
\text { currents) }\end{array}$ \\
\hline & 2C: Crystal-rich volcanogenic deposits & $\begin{array}{l}\text { Sediment gravity flow processes (turbidity } \\
\text { currents) }\end{array}$ \\
\hline & 2D: Glauconitic-rich volcaniclastites & $\begin{array}{l}\text { Sediment gravity flow processes (turbidity } \\
\text { currents) }\end{array}$ \\
\hline $\begin{array}{l}\text { Type } 3 \\
\text { Mixing of Volcaniclastic Sediments } \\
\text { with Marine Deposits }\end{array}$ & $\begin{array}{l}\text { 3: Marls, calcareous marls, and marly limestones } \\
\text { with volcaniclastic material }\end{array}$ & $\begin{array}{l}\text { Fallout mixing with marly calcareous marine } \\
\text { sedimentation }\end{array}$ \\
\hline
\end{tabular}

opening of the Sardinia Trough during the drift rotation of the Sardinia-Corsica Block.

Sardinia has often been proposed as the source area for the Apennine volcaniclastites, as recently reported by Perri et al. (2012). However, the location of Sardinia during the Late Oligocene-Early Miocene would not agree with results of our study and in particular with the presence of epiclastic processes because Sardinia was palaeogeographically located too far from the Umbria-Romagna-Marche sedimentary basins (Fig. 4). In particular, the distance between Sardinia and basins in the reconstructed palaeogeographic framework (Fig. 4) is estimated to be several hundred kilometres. Moreover, the epiclastic processes (turbidites) from Sardinia would have been prevented by the complex palaeogeography of the western Mediterranean region in the time span considered (Dewey et al. 1989; Doglioni 1992; Guerrera et al. 1993, 2005, 2012b; Maillard and Mauffret 1993; de Capoa et al. 2002; among others). A possible relationship with Sardinia volcanism can be invoked only for thin and very fine-grained volcaniclastic pelites (fallout processes) deposited between 22-20 and 17-13 Ma, when a large volume of ignimbrites and fallout deposits developed in Sardinia (Assorgia et al. 1997).

The Sardinia Trough exemplifies an important fossil record of a small distance between primary volcanic centres and depositional areas. Our studies on the tectonosedimentary evolution of this trough (Mattioli et al. 2000; Guerrera et al. 2004) point to volcano-sedimentary successions deposited in marine basins near $50-100 \mathrm{~km}$ from the primary remnants of volcanic sources. This may be a reference evolutionary model also for the Bisciaro depositional areas that therefore could not be fed by the Sardinia area, as indicated by previous authors. Therefore, most of the Late Oligocene-Early Miocene volcaniclastic material dispersed throughout the Apennines, Maghrebides, and Betides were erupted by volcanic source vents located closer than Sardinia. In fact, available data seem to indicate the existence of calc-alkaline volcanic arc systems adjacent to the depositional area of the Bisciaro Fm. and located in an internal position with respect to the basins themselves.

Palaeotectonic and palaeogeographic reconstructions of the central-western Mediterranean region during the Late Oligocene-Aquitanian and Burdigalian-Langhian times evidence the presence of a microplate (Mesomediterranean Microplate) located between the European and African Plates (Doglioni 1992; Guerrera et al. 1993, 2005; 2012b; among others) and bordered northwards by a transform fault separating from the European margins (Guerrera et al. 2012b; Alcalá et al. 2013) and southward by another oceanic area called the Maghrebian Flysch Basin-Lucania Basin (de Capoa et al. 2003; Perrone et al. 2008; and references therein).

On the basis of both transport and sedimentation processes recognized for the volcaniclastic sediments of the "Bisciaro volcaniclastic event", and the short distance and the palaeogeography between volcanic areas and the sedimentary basins (Guerrera et al. 1993, 2005, 2012b, Guerrera and Martin-Martin 2014; Alcalá et al. 2013), the main volcanism affecting the Bisciaro depositional area should probably be located along the external active margins of this Microplate and/or, in a late evolutionary stage, along the suture zone between the Adria Plate and the Mesomediterranean Microplate (Fig. 4) in a way different from that indicated previously by Critelli et al. (2013) who located volcanic arcs only in Sardinia.

\begin{tabular}{llll|} 
Journal : Large 531 & Dispatch : 27-12-2014 & Pages : 24 \\
Article No : 1131 & $\square \quad$ LE & $\square$ TYPESET \\
MS Code : IJES-D-14-00133 & $\square \quad C P$ & $\square$ DISK \\
\hline
\end{tabular}




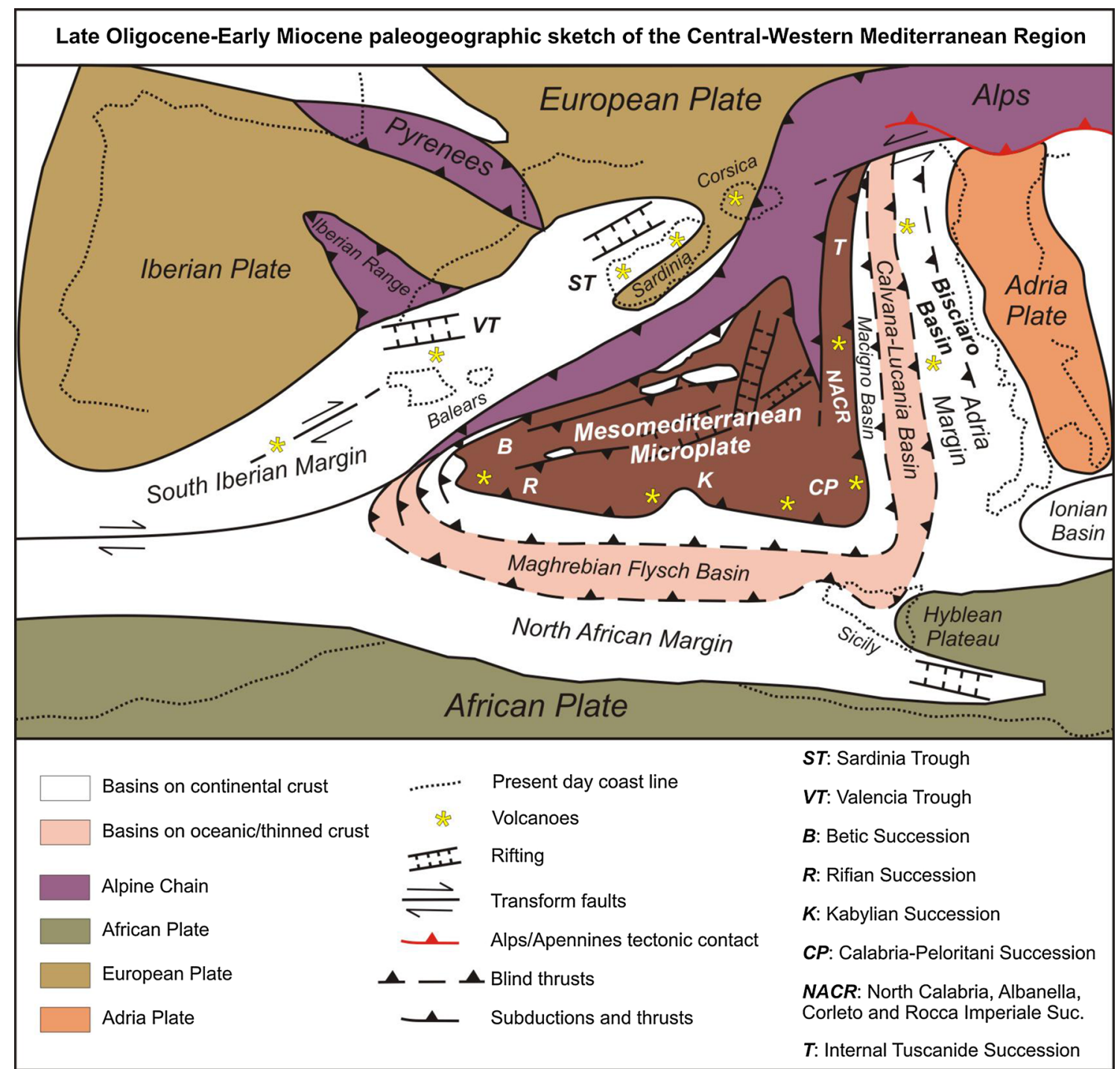

Fig. 4 Palaeogeographic and geodynamic model of the central-western Mediterranean area showing the relationships between volcanic systems and sedimentary basins. Volcanoes located on Adria Margin

Intense volcanism should be located also on the southern external margin of the Mesomediterranean Microplate, which deformed starting from the Aquitanian-Burdigalian when the adjacent sedimentary basins located in more external position (Tusa Flysch Fm. in the southern Apennines and Sicily correlate with the Flysch along North Africa and the Betic Cordillera), were affected by a marked volcaniclastic supply (Table 5; Fig. 4).

Late Oligocene-Early Miocene primary volcanoes might have undergone quick erosional processes and/ or subsidence, and remnants of volcanic bounding could also have been buried and concealed in depth by underthrusting during the post-Early Miocene tectonic evolution (e.g. central Apennines, Pieve S. Stefano 1 and Mortara 1 wells). In addition, the volcanic activity could have activated during the continental collision stage after the closure of the Calvana-Lucania Basin

occurred along major strike-slip faults affecting the plate margin convergence (Sylvester 1988). The Late OligoceneEarly Miocene kinematic evolution of the central-western Mediterranean (Dewey et al. 1989) could have accounted for short-lived volcanoes linked to a dominant transformrelated tectonics. Thus, part of the eruptive centres located along these faults constituted transient volcanic systems above a tectonic mobile substratum.

\section{Conclusions}

The above-reported considerations allow some main constraints to reconstruct the relationships between volcaniclastic supply and depositional sites of the "Bisciaro

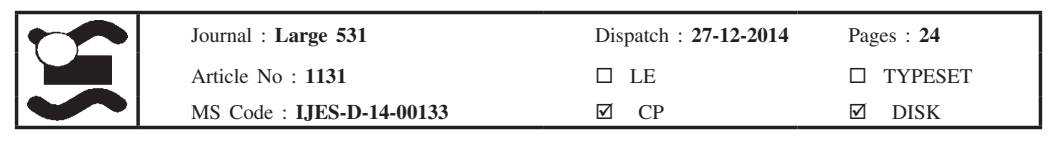


volcaniclastic event" and at the same time imply many considerations for the reconstruction of the geodynamic evolution of the central-western Mediterranean region during the Early Miocene.

The main conclusions are as follows:

1. The Early Miocene "Bisciaro volcaniclastic event" is recorded within a succession recognized in the Umbria-Romagna-Marche Apennines in which the start of the volcaniclastic supply is marked by the Aquitanian "Raffaello" marker bed. The volcaniclastic event ends in the Late Burdigalian-Early Langhian within the lower part of the Schlier Fm.

2. In the "Bisciaro volcaniclastic event", three types of petrofacies have been recognized (Tables 1, 2, 3, 5):

- Type 1 Pyroclastic Deposits, including three subpetrofacies: 1A, Vitroclastic/crystallo-vitroclastic tuffs; 1B, Bentonitic deposits; and 1C, Ocraceous and blackish layers.

- Type 2 Resedimented Syn-Eruptive Volcanogenic Deposits, including four sub-petrofacies: 2A, Highdensity volcanogenic turbidites; $2 \mathrm{~B}$, Low-density volcanogenic turbidites; $2 \mathrm{C}$, Crystal-rich volcanogenic deposits; and 2D, Glauconitic-rich volcaniclastites.

\section{- Type 3 Mixing of Volcaniclastic Sediments with} Marine Deposits constituted by marls, calcareous marls, and marly limestones containing volcaniclastic material.

3. Two main depositional processes of the volcaniclastic material have been recognized: (a) fallout and/or pyroclastic flows and (b) sediment gravity flow (turbidity currents). However, a slight predominance of the fallout deposition has been indicated.

4. The Bisciaro succession results from a mixing of volcaniclastic materials coming from strong volcanic activity with contemporaneous hemipelagic marine deposits during the Early Miocene. The volcaniclastic material is linked strictly to the coeval primary volcanic activity, the volcaniclastic products being well correlated with many others across the central-western Mediterranean area. Thus, this volcaniclastic event can be considered as a regional marker useful for palaeogeographic reconstructions.

5. The high amount of volcaniclastic materials points to the occurrence of different contemporaneous volcanic systems near the sedimentary basins with disparate specific geodynamic contexts, as attested to by acid (dacitic, rio-dacitic, rhyolitic, etc.) to acid-intermediate (basaltic, andesitic, etc.) volcanic products of a calkalkaline volcanism, presumably connected to a subduction zone. The subduction firstly occurred between the oceanic crust of the Calvana Basin beneath the Mesomediterranean Microplate (Andean-like subduction). With the closure of this basin and the complete consumption of the oceanic crust, a continental collision developed with a subduction towards the east of the continental crust of the Mesomediterranean Microplate beneath the Adria Margin.

6. The scarcity of remnants of products related to primary volcanic activity is probably due to the following factors: (a) these products could have been buried and concealed in depth by thrusting processes during the post-Early Miocene tectonic evolution (e.g. Apennines and Po Plain); (b) the "cannibalization" of primary volcanoes during subduction activity; (c) a quick erosion of the inconsistent explosive volcanic centres; and (c) the tectonic mobility due to strike-slip faults along which the volcanic activity occurred. In fact, the kinematic evolution of the central-western Mediterranean (Dewey et al. 1989) could have accounted for shortlived volcanoes prevalently linked to transform zone tectonics.

7. The Late Oligocene-Early-Middle Miocene palaeogeographic-palaeotectonic model of the central-western Mediterranean area (Fig. 4) can explain the data compiled in relation to the presence of a microplate (Mesomediterranean Microplate) located between the European and African Plates. Taking into account the transport and sedimentation processes recognized for the volcaniclastic material, the primary volcanic systems must be located along the external (southern) active margins of the Mesomediterranean Microplate and probably also on the internal margin of the Adria Plate. The volcanism was probably related to the westward subduction of the Calvana Basin and the successive continental collision between the Mesomediterranean Microplate and Africa-Adria Plate. At the same time, a strong volcanism developed along the rifting of the Valencia Basin caused by the extension-related drifting-rotation of the Corsica-Sardinia Block also determining the intense volcanic activity of the Sardinia Trough.

8. The data gathered imply that the distance between volcanoes and depositional area of the "Bisciaro volcaniclastic event" must be less than $100 \mathrm{~km}$, and in some cases, the volcanic centres could be located directly on the basin margin.

9. The Early Miocene reconstruction of the palaeogeographic and geodynamic relationships between volcaniclastic deposits and volcanoes of different sectors in the central-western peri-Mediterranean region is complex (Guerrera et al. 1998; cum bibl.). However, some identified Late Oligocene-Early Miocene primary volcanic products (e.g. Pieve S. Stefano 1 drilling; Anelli et al.

\begin{tabular}{|l|ll|} 
Journal : Large 531 & Dispatch : 27-12-2014 & Pages : 24 \\
Article No : 1131 & $\square$ LE & $\square$ TYPESET \\
MS Code : IJES-D-14-00133 & $\square \quad C P$ & $\square$ DISK \\
\hline
\end{tabular}


1992; Mortara 1 drilling; Cassano et al. 1986; Bonci et al. 1994; Sardinia; Mattioli et al. 2000; Guerrera et al. 2004; Valencia Through; Maillard and Mauffret 1993; Algeria; Monié et al. 1992; and discussion in Guerrera et al. 1998) may explain the presence of volcaniclastic products in different considered palaeogeographic context that are related to the various geodynamic settings of the peri-Mediterranean chains considered.

Acknowledgments This research was supported by Urbino University funds (responsibles F. Guerrera and M. Tramontana); by CGL2011-30153-CO2-02 and CGL2012-32169 Research Project (Spanish Ministry of Education and Science); and by Research Groups and projects of the Generalitat Valenciana and Alicante University (CTMA-IGA). The authors thank their colleague Michele Mattioli for the useful suggestions. The authors are very grateful to a native speaker (David Nesbitt) for improving the English version of the manuscript. The revisions performed by S. Critelli and topicEditor Christoph Breitkreuz are also acknowledged.

\section{References}

Alcalá FJ, Guerrera F, Martin-Martin M, Raffaelli G, Serrano F (2013) Geodynamic implications derived from "Numidianlike" distal turbidites deposited along the Internal-External Domain Boundary of the Betic Cordillera (S Spain). Terra Nova 25:119-129

Amorosi A, Coccioni R, Tateo F (1994) The volcaniclastic bodies in the Early Miocene Bisciaro Formation (Umbria-Marche Apennines, central Italy). Giorn Geol 56(1):33-46

Anelli L, Gorza M, Pieri M, Riva M (1992) Dati di pozzi profondi dell'Appennino settentrionale. $76^{\circ}$ Riunione Estiva Soc Geol Ital, Firenze, 1992, Abstract:191

Arias C, Castro JM, Chacón B, Company M, Crespo-Blanc A, Diaz de Federico A, Estévez A et al (2004) Zonas Externas Béticas. In: Vera JA (ed) "Geología de España" (2004), Sociedad Geológica de España IGME: $1-884$

Assorgia A, Barca S, Spano C (1997) A synthesis on the Cenozoic stratigraphic, tectonic and volcanic evolution in Sardinia (Italy). Boll Soc Geol Ital 116:407-420

Bally AW, Burbi L, Cooper C, Ghelardoni R (1988) Balanced sections and seismic reflection profiles across the central Apennines. Mem Soc Geol Ital 35:257-310

Balogh K, Delle Rose M, Guerrera F, Ravasz-Baranyai L, Veneri F (1993) New data concerning the inframiocenic "Bisciaro vocaniclastic events" (Umbro-Marche Apennines) and comparison with similar occurrences. Giorn Geol 55(2):83-104

Barchi MR, Minelli G, Pialli G (1998) The CROP 03 profile: a synthesis of results on deep structures of the Northern Apennines. Mem Soc Geol Ital 52:383-400

Bonardi G, de Capoa P, Di Staso A, Estevez A, Martín-Martín M, Martín-Rojas I, Perrone V, Tent-Manclús JE (2003) Oligoceneto-Early Miocene depositional and structural evolution of the Calabria-Peloritani Arc southern terrane (Italy) and geodynamic correlations with the Spain Betics and Morocco Rif. Geodin Acta 16:149-169

Bonci MC, Cortesogno L, Gaggero L, Negri A, Radrizzani CP (1994) Preliminary data on the Oligo-Miocene volcanism in the Garbagna area (Al, F. Voghera). Atti Tic Sc Terra I:283-296

Borsetti AM, Cati F, Mezzetti R, Savelli C, Toni G (1984) Le intercalazioni vulcanoclastiche nei sedimenti oligo-miocenici
dell'Appennino settentrionale e centrale (dati petrologici, K/Ar e micropaleontologici). Giorn Geol 45(2):159-198

Boulin J, Bourgois J, Chauve P, Durand Delga M, Magne J, Mathis V, Peyre Y, Rivière M, Vera JA (1973) Age miocène inférieur de la formation de la Viñuela, discordante sur les nappes internes bétiques (Province de Malaga, Espagne). C R Acad Sci Paris 276:1245-1248

Caracciolo L, Critelli S, Innocenti F, Kolios N, Manetti P (2011) Unravelling provenance from Eocene-Oligocene sandstones of the Thrace Basin, North-east Greece. Sedimentology 58:1988-2011

Caracciolo L, von Eynatten H, Tolosana-Delgado R, Critelli S, Manetti P, Marchev P (2012) Petrological, geochemical, and statistical analysis of Eocene-Oligocene sandstones of the Western Thrace Basin, Greece and Bulgaria. J Sed Res 82:482-498

Carmisciano R, Coccioni R, Corradini D, D'Alessandro A, Guerrera F, Loiacono F, Moretti E, Puglisi D, Sabato L (1989) Nuovi dati sulle "Successioni Miste" inframioceniche dell'Algeria (Grande Kabilia) e della Sicilia (Monti Nebrodi): confronti con analoghe successioni torbiditiche nell'Arco di Gibilterra e nell'Appennino lucano. Mem Soc Geol Ital 38:551-576

Cas RAF (1979) Mass-flow arenites from a Palaeozoic interarc basin, New South Wales, Australia: mode and environment of emplacement. J Sed Petrol 49:29-44

Cas RAF, Wright JM (1987) Volcanic Succession, modern and ancient. A geological approach to processes, products and successions. Allen \& Unwin Ed., London

Cassano E, Anelli I, Fichera R, Cappelli V (1986) Pianura Padana Interpretazione integrata di dati geofisici e geologici. Soc Geol Ital $73^{\circ}$ Congress, AGIP Ed., p 27

Channell JET, D'Argenio B, Horvath F (1979) Adria, the African Promontory, in Mesozoic Mediterranean palaeogeography. Earth Sci Rev 15:213-292

Clari P, Pirini C, Ricci B, Ruffini R, Valleri G (1988) Livelli cineritici miocenici nel Monferrato. Rend Soc Geol Ital 11:293-296

Coccioni R, Guerrera F, Veneri F (1988) Segnalazione di un intervallo piroclastico ("Mega-P") di notevole spessore nel Bisciaro inframiocenico di Arcevia (Appennino Marchigino). Boll Soc Geol Ital 107:25-32

Coccioni R, Langenheim VE, Montanari A (1989) The "Livello Raffaello" in the Umbria-Marches Apennines: a regional volcaniclastic marker bed at the boundary between the Scaglia Cinerea and the Bisciaro Formations (lowermost Miocene). In: Abstract of the 28th international geological congress, Washington, DC, USA, July 9-19, pp 308-309

Coccioni R, Montanari A (1992) The "Livello Piero della Francesca" in the Umbria-Marche Apennines, Italy: a regional volcaniclastic marker bed at the boundary between the Bisciaro and Schlier/Marne con Cerrogna Formations (Lower Miocene). IUGS-SOG, Portonovo, 1992, Abstract:41-42

Coccioni R, Morandi N, Tateo F (1994) The Livello Raffaello (Early Miocene) in the Umbria-Marche Apennines, Italy: stratigraphy, paleontology, mineralogy, and geochemistry. Giorn Geol 56(1):55-78

Coward MP, De Donatis M, Mazzoli S, Paltrinieri W, Wezel FC (1999) Frontal part of the northern Apennines fold and thrust belt in the Romagna-Marche area (Italy): shallow and deep structural styles. Tectonics 18:559-574

Critelli S, Le Pera E (1990) Litostratigrafia e composizione della Formazione di Pollica (Gruppo del Cilento, Appennino meridionale). Boll Soc Geol Ital 109:511-536

Critelli S, Monaco C (1993) Depositi vulcanoclastici nell'unità del flysch Calabro-Lucano (Complesso Liguride, Appennino meridionale). Boll Soc Geol Ital 112:121-132

Critelli S, Ingersoll RV (1995) Interpretation of neovolcanic versus palaeovolcanic sand grains: an example from Miocene 
deep-marine sandstone of the Topanga Group (Southern California). Sedimentology 42:783-804

Critelli S, Marsaglia KM, Busby CJ (2002) Tectonic history of a Jurassic backarc basin sequence (the Gran Cañon Formation) based on compositional modes of tuffaceous deposits. Geol Soc Am Bull 114(5):515-527

Critelli S, Mongelli G, Perri F, Martín-Algarra A, Martín-Martín M, Perrone V, Dominici R, Sonnino M, Zaghloul MN (2008) Sedimentary Evolution of the Middle Triassic-Lower Jurassic continental redbeds from Western-Central Mediterranean Alpine Chains based on geochemical, mineralogical and petrographical tools. J Geol 116:375-386

Critelli S, Muto F, Tripodi V, Perri F (2013) Link between thrust tectonics and sedimentation processes of stratigraphic sequences from the southern Apennines foreland basin system, Italy. Rendiconti Online Soc Geol Ital 25:21-42

D'Atri A, Tateo F (1994) Volcano-sedimentary beds of Oligocene age from the Tertiary Piedmont Basin (NW Italy): biostratigraphy and mineralogy. Giorn Geol 56(1):79-95

de Capoa P, Di Staso A, Guerrera F, Perrone V, Tramontana M, Zaghloul MN (2002) The Lower Miocene volcaniclastic sedimentation in the Sicilian sector of the Maghrebian Flysch Basin: geodynamic implications. Geodin Acta 15:141-157

de Capoa P, Di Staso A, Guerrera F, Perrone V, Tramontana M (2003) The extension of the Maghrebian Flysch Basin in the Apenninic Chain: paleogeographic and paleotectonic implications. Atti Congr. "Etat des connaissances géologiques des régions nord du Maroc: la Chaîne Rifaine dans son cadre Méditérranéen occidental, Rabat (Maroc). Trav Inst Sci Rabat Géogr Phys 21:77-92

de Feyter AJ (1991) Gravity tectonics and sedimentation of the Montefeltro. Geologica Ultraiectina. Ph.D. Thesis University of Utrecht:1-168

Deino A, Channel J, Coccioni R, De Grandis G, De Paolo DJ, Fornaciari E, Emmanuel L, Laurenzi MA, Montanari A, Rio D, Renard M (1997) Integrated stratigraphy of the upper Burdigalian-lower Langhian section at Moria (Marche Region, Italy). In: Montanari A, Odin GS, Coccioni R (eds) Miocene stratigraphy: an integrated approach, developments in paleontology and stratigraphy, vol 15, pp 315-342

Delle Rose M, Guerrera F, Renzulli A, Ravasc-Baranyai L, Serrano F (1994a) Stratigrafia e petrografia delle Marne di Vicchio (Unità Tettonica Cervarola) dell'alta Val Tiberina (Appennino ToscoRomagnolo). Boll Soc Geol Ital 113:675-708

Delle Rose M, Guerrera F, Renzulli A, Serrano F (1994b) Stratigraphic and volcaniclastic events in the Vicchio Marls Auct. (Cervarola Tectonic Unit) along the Monte Fatucchio section (northern Apennines, Italy). Giorn Geol 56(1):97-114

Dewey JF, Helman ML, Turco E, Hutton DHW, Knott SD (1989) Kinematics of the western Mediterranean. Alp Tecton Spec Publ 45:265-283

Di Staso A, Giardino S (2002) New integrate biostratigraphic data about the Saraceno Formation (North-Calabrian Unit; Southern Apennines). Boll Soc Geol Ital, vol. spec. 1:517-526

Di Staso A, Perrotta S, Guerrera F, Perrone V, Tramontana M (2009) New biostratigraphic and petrographic data from the Poggio Carnaio Sandstone Fm. (Val Marecchia Nappe): insights into the tectonic evolution of the Northern Apennines. Ital J Geosci 128(2):443-454

Doglioni C (1992) Main differences between thrust belts. Terra Nova 4:152-164

Donatelli U, Tramontana M (2012) Jurassic carbonate depositional systems of the Mt. Catria-Mt. Acuto area (Umbria-Marche Apennines, Italy). Ital J Geosci 131:3-18

Donatelli U, Tramontana M (2014) Platform-to-basin facies transition and tectono-sedimentary processes in the Jurassic deposits of Furlo area (Umbria-Marche Apennines, Italy). Facies 60:541-560

Dubbini A, Guerrera F, Sandroni P (1992) Nuovi dati sullo Schlier dell' Appennino umbro-marchigiano. Giorn Geol 53(2):115-130

Faugeres JC, Broquet P, Duée G, Imbert P (1992) Episodes volcanosedimentaires et paleo-courants dans le Numidien externe de Sicile: les tuffites et contourites de Karsa. C R Acad Sci Paris 315:479-486

Fisher RV (1984) Submarine volcaniclastic rocks. In: Kokelaar BP, Howells MF (eds) Marginal basin geology. Volcanic and associated sedimentary and tectonic processes in modern and ancient marginal basins. Blackwell Scientific, Hoboken, pp 5-27

Fontana D (1980) Caratteri petrografici e sedimentologici delle Arenarie di Manciano nella Toscana meridionale. Min Petrogr Acta 24:77-94

Guerrera F (1977) Geologia del Bisciaro dei Monti della Cesana (Urbino). Giorn Geol 2(I):109-132

Guerrera F (1979) Stratigrafia e sedimentologia dei livelli "tripolacei" del Miocene inferiore-medio appenninico. Boll Serv Geol d'It 99:233-262

Guerrera F (1981/82) Successions turbiditiques dans les flysches maurétanien et numidien du Rif (Maroc). Rev Géol Dynamique Geogr Phys 23(2):85-96

Guerrera F, Tonelli G, Veneri F (1986) Caratteri lito-sedimentologici e mineralogico-petrografici di vulcanoclastiti mioceniche presenti nella successione umbro-marchigiana. Boll Soc Geol Ital 105:307-325

Guerrera F, Veneri F (1989) Neogene and Pleistocene volcaniclastites of the Apennines (Italy). Geol Mijinbouw 68:381-390

Guerrera F, Martin-Algarra A, Perrone V (1993) Late OligoceneMiocene syn-/late-orogenic successions in Western and Central Mediterranean Chains from the Betic Cordillera to the Southern Apennines. Terra Nova 5:525-544

Guerrera F, Mattioli M, Puglisi D, Renzulli A, Santi P, Veneri F, Assorgia A, Balogh K (1998) An overview of the Upper Oligocene-Lower Miocene volcanogenic sediments in the Western Mediterranean: what volcanic source areas and geodynamic constraints? Atti "Xth Congress R.C.M.N.S. "New lights on Mediterranean Chronology, Tethys-Parathetys connections". Rom J Stratigr 78:43-56

Guerrera F, Mattioli M, Serrano F, Tramontana M, Raffaelli G (2004) Stratigraphy of the Miocene syn-rift volcano-sedimentary succession in a sector of the central-southern Sardinia Trough (Italy). Geol Carpath 55(1):51-63

Guerrera F, Martin-Martin M, Perrone V, Tramontana M (2005) Tectono-sedimentary evolution of the southern branch of the Western Tethys (Maghrebian Flysch Basin and Lucanian Ocean). Terra Nova 17:358-367

Guerrera F, Tramontana M, Donatelli U (2012a) Space/time tectono-sedimentary evolution of the Umbria -Romagna-Marche Miocene Basin (North Apennines, Italy). Swiss J Geosci 105(3):325-341

Guerrera F, Martín-Algarra A, Martín-Martín M (2012b) Tectono-sedimentary evolution of the "Numidian Formation" and Lateral Facies (southern branch of the western Tethys): constraints for centralwestern Mediterranean geodynamics. Terra Nova 24:34-41

Guerrera F, Martin-Martin M (2014) Geodynamic events reconstructed in the Betic, Maghrebian, and Apennine Chains (central-western Tethys). Bull Soc Géol Fr 185(5):329-341

Lavecchia G, Brozzetti F, Barchi RM, Keller J, Menichetti M (1994) Seismotectonic zoning in east-central Italy deduced from the analysis of the Neogene to present deformations and related stress fields. Geol Soc Am Bull 106:1107-1120

Mahlburg-Kay S, Ramos V A (2006) Evolution of an Andean Margin: a tectonic and magmatic view from the Andes to the Neuquén Basin (35 $-39^{\circ}$ lat). Geol Soc Am Spec Pap 407

\begin{tabular}{llll|} 
Journal : Large 531 & Dispatch : 27-12-2014 & Pages : 24 \\
Article No : $\mathbf{1 1 3 1}$ & $\square$ LE & $\square$ TYPESET \\
MS Code : IJES-D-14-00133 & $\square \quad C P$ & $\square$ DISK \\
\hline
\end{tabular}


Maillard A, Mauffret A (1993) Structure et volcanisme de la fosse de Valence (Méditerranée nord-occidentale). Bull Soc géol Fr 164(3):365-383

Marchegiani L, Bertotti G, Cello G, Deiana G, Mazzoli S, Tondi E (1999) Pre-orogenic tectonics in the Umbria-Marche sector of the Afro-Adriatic continental margin. Tectonophysics 315:123-143

Martín-Algarra A (1987) Evoluciòn geológica Alpina del contacto entre las Zonas Internas y las Zonas Externas de la Cordillera Bética. Ph. D. Thesis University of Granada, pp 1-1171

Mattioli M, Guerrera F, Tramontana M, Raffaelli G, D'Atri M (2000) High-Mg Tertiary basalts in Southern Sardinia (Italy). Earth Planet Sci Lett 179:1-7

Mattioli M., Di Battistini G., Zanzucchi G (2002) Geochemical features of the Tertiary buried Mortara volcanic body (Northern Apennines, Italy). Boll Soc Geol Ital, vol. spec. 1:239-249

Mazzoli S, Helman M (1994) Neogene patterns of relative plate motion for Africa-Europe: some implications for recent central Mediterranean tectonics. Geol Rundschau 83:464-468

Mazzoli S, Lanci L, De Donatis M (2001) Paleomagnetic rotations in thrust belts: a case-study from the Marche-Romagna area (Northern Apennines, Italy). J Geodyn 32:373-393

Mazzoli S, Pierantoni PP, Borraccini F, Paltrinieri W, Deiana G (2005) Geometry, segmentation pattern and displacement variations along a major Apennine thrust zone, central Italy. J Struct Geol 27:1940-1953

Mezzetti R, Olivieri R (1964) Intercalazioni cineritiche di età oligocenica e miocenica nell'Appennino centro-settentrionale. Osservazioni sedimentologiche, petrografiche e microstratigrafiche. Miner Petrogr Acta 10:129-147

Mezzetti R (1969) Studio petrografico di ceneri vulcaniche appenniniche. 1) Le intercalazioni langhiane dell'Emilia e delle Marche. Miner Petrogr Acta 15:9-34

Mezzetti R, Moranti N, Tateo F, Dondi M (1992) Il contributo vulcanoderivato in successioni pelitiche oligo-mioceniche dell'Appennino settentrionale. Giorn Geol 53:167-185

Monié P, Montigny R, Maluski H (1992) Age burdigalien de la tectonique ductile extensive dans le massif de l'Edough (Kabylie, Algérie). Données radiometriques ${ }^{39} \mathrm{Ar}-{ }^{40} \mathrm{Ar}$. Bull Soc Géol Fr 163:571-584

Montanari A, Langenheim V, Coccioni R (1988) Stratigraphy and geochronological potential of the pelagic and emipelagic Miocene sequence of the Northeastern Apennines. Bull Liais Inf Proj 196(7):17-23

Montanari A, Carey S, Coccioni R, Deino A (1994) Early Miocene tephra in the Apennines pelagic sequence: An inferred Sardinian provenance and implications for western Mediterranean tectonics. Tectonics 13:1120-1134

Morandi N, Tateo F (1992) Mineralogy of pelitic "Bisciaro" \& "Schier" sediments in the S. Croce and Moria Sections (Marche Region, Italy). Miner Petrogr Acta 35:235-255

Papini M, Vannucci S (1993) Intercalazioni vulcanoclastiche e silicee nelle Arenarie del Cervarola del versante orientale di M. Giovi (Firenze). Giorn Geol 55:51-69

Perri F, Critelli S, Cavalcante F, Mongelli G, Dominici R, Sonnino M, De Rosa R (2012) Provenance signatures for the Miocene volcaniclastic succession of the Tufiti di Tusa Formation, southern Apennines, Italy. Geol Mag 149(3):423-442

Perri F, Critelli S, Martín-Algarra A, Martín-Martín M, Perrone V, Mongelli G, Zattin M (2013) Triassic redbeds in the Malaguide Complex (Betic Cordillera-Spain): petrography, geochemistry and geodynamic implications. Earth Sci Rev 117:1-28

Perrone V (1987) I depositi miocenici della dorsale di Monte Soprano (Appennino campano): segnalazione di vulcanismo andesitico e nuova interpretazione. Boll Soc Geol Ital 106:3-12
Perrone V, de Capoa P, Cesarini F (1998) Remise en question, à propos de la nappe du Val Marecchia, d'attributions paléogéographique et structurales de l'Apennin Nord-oriental (Italie). C R Acad Sci Paris 326:347-353

Perrone V, Di Staso A, Perrotta S (2008) The evolution of the Western Adriatic margin and contiguous oceanic area: open problems and working hypotheses. Boll Soc Geol Ital 127:357-373

Plesi G, Galli M, Daniele G (2002) The Monti Rognosi Ophiolithic Unit (cfr. Calvana Unit Auct.) paleogeographic position in the External Ligurian Domain, relationships with the tectonic units derived from the Adriatic margin. Boll Soc Geol Ital 1:273-284

Pettijohn FJ, Potter PE, Siever R (1972) Sand and sandstones. Springer, Berlino

Rehault JP (1981) Evolution tectonique et sédimentaire du bassin Ligure (Méditerranée occidentale). Thesis Université de Paris VI

Rivière M, Courtois C (1975) Étude minéralogique et géochimique des tuffites burdigaliennes de la région de Malaga (Espagne): intérêt des diagrammes de répartition des terres rares. C R Acad Sci Paris 280:1645-1648

Rivière M, Bellon H, Bonnot-Courtois Ch (1981) Aspects géochimiques et géochronologiques du volcanisme pyroclastique foré dans le Golfe de Valence: Site 123 DSDP, Leg 13 (Espagne). Consequences geodynamiques. Mar Geol 41:295-307

Ruffini R (1995) Evidences of Tertiary volcanic activity in the Western Alps: problem and hypotheses. Plinius 13:214-220

Santo A, Senatore MR (1992) La successione stratigrafica dell'Unità Dauna a Monte Sidone (Castelluccio, Valmaggiore, Foggia) Mem Soc Geol Ital 41:431-438

Savelli C, Guerrera F, Erwan G (2007) Western Mediterranean Geodynamics: a look for the period of westward subduction initiation. $6^{\circ}$ Forum Italiano di Scienze della Terra, Rimini 12-14 settembre 2007, vol. 2/T120, Abstract:p.141

Selli R (1952) Il Bacino del Metauro. Giorn Geol 24:1-268

Selli R (1967) Cenni sul Neogene dell'Avanfossa marchigiana. In. "Guida alle escursioni", IV Congr Neog Medit, Bologna 1967

Shiner P, Beccacini A, Mazzoli S (2004) Thin-skinned versus thickskinned structural models for Apulian carbonate reservoirs: constraints from the Val D'Agri Fields. Mar Pet Geol 21:805-827

Simakin AG (2014) Numerical modelling of the late stage of subduction zone transference after an accretion event. Terra Nova 26(1):22-28

Soria JM, Estévez A, Serrano F (1992) Silexites et roches volcanoclastiques burdigaliennes de la Zone subbétique centrale (région du Río Fardes-Mencal, Espagne méridionale). Signification géodynamique. C R Acad Sci Paris 314:1219-1226

Sylvester AG (1988) Strike-slip faults. Geol Soc Am Bull 100:1666-1703

Tateo F (1993) Intercalazioni vulcano-sedimentarie nella Formazione di Antognola: le sezioni "Rio Nespolo" e "M. Varano" (Oligocene superiore, Appennino parmense). Min Petrogr Acta 36:61-79

Turco E, Macchiavelli C, Mazzoli S, Schettino A, Pierantoni PP (2012) Kinematic evolution of Alpine Corsica in the framework of Mediterranean mountain belts. Tectonophysics. doi:10.1016/j.tecto.2012.05.010

Wright JV, Mutti E (1981) The Dali Ash, Island of Rhodes, Greece: a problem in interpreting submarine volcanogenic sediments. Bull Volcanol 44(2):153-166

Zaghloul MN, Guerrera F, Loiacono F, Maiorano P, Puglisi D (2002) Stratigraphy and petrography of the Beni Ider Flysch in the Tétouan area (Rif Chain, Morocco). Boll Soc Geol Ital 121:69-85

Zeck HP, Maluski H, Kristensen AB (2000) Revised geochronology of the Neogene calc-alkaline volcanic suite in Sierra de Gata, Alboran volcanic province, SE Spain. J Geol Soc $157: 75-81$ 
Zuffa GG (1985) Optical analyses of Arenites: Influence of methodology on compositional results. In: Provenance of Arenites (GG Zuffa ed.). NATO ASI sn148, D Reidel Publ Co: $165-189$
Zuffa GG (1987) Unravelling hinterland and offshore palaeogeography from deep-water arenites. In: Legget JK, Zuffa GG (eds) Deep-marine clastic sedimentology: concepts and case study. Graham and Trotman, pp 39-61 